\title{
Transcriptional Regulation of Genes Involved in Zinc Uptake, Sequestration and Redistribution Following Foliar Zinc Application to Medicago sativa
}

\author{
Alessio Cardini ${ }^{1, \dagger}{ }^{,}$Elisa Pellegrino ${ }^{1, *,+} \oplus$, Philip J. White ${ }^{2}$, Barbara Mazzolai ${ }^{3}$, Marco C. Mascherpa ${ }^{4}(\mathbb{D}$ and \\ Laura Ercoli ${ }^{1}$ (D) \\ 1 Institute of Life Sciences, Scuola Superiore Sant'Anna, 56127 Pisa, Italy; alessio.cardini@santannapisa.it (A.C.); \\ laura.ercoli@santannapisa.it (L.E.) \\ 2 Department of Ecological Science, The James Hutton Institute, Invergowrie, Dundee DD2 5DA, UK; \\ philip.white@hutton.ac.uk \\ 3 Center for Micro-BioRobotics, Istituto Italiano di Tecnologia, Pontedera, 56025 Pisa, Italy; \\ barbara.mazzolai@iit.it \\ 4 Istituto di Chimica dei Composti Organo Metallici, National Research Council (CNR), 56124 Pisa, Italy; \\ marcocarlo.mascherpa@pi.iccom.cnr.it \\ * Correspondence: elisa.pellegrino@santannapisa.it \\ + These authors contributed equally to this work.
}

check for updates

Citation: Cardini, A.; Pellegrino, E.; White, P.J.; Mazzolai, B.; Mascherpa, M.C.; Ercoli, L. Transcriptional

Regulation of Genes Involved in Zinc Uptake, Sequestration and

Redistribution Following Foliar Zinc Application to Medicago sativa. Plants 2021, 10, 476. https://doi.org/ $10.3390 /$ plants10030476

Academic Editor:

Gokhan Hacisalihoglu

Received: 22 January 2021

Accepted: 25 February 2021

Published: 3 March 2021

Publisher's Note: MDPI stays neutral with regard to jurisdictional claims in published maps and institutional affiliations.

Copyright: (c) 2021 by the authors. Licensee MDPI, Basel, Switzerland. This article is an open access article distributed under the terms and conditions of the Creative Commons Attribution (CC BY) license (https:/ / creativecommons.org/licenses/by/ $4.0 /)$.
Abstract: Zinc (Zn) is an essential micronutrient for plants and animals, and Zn deficiency is a widespread problem for agricultural production. Although many studies have been performed on biofortification of staple crops with Zn, few studies have focused on forages. Here, the molecular mechanisms of $\mathrm{Zn}$ transport in alfalfa (Medicago sativa L.) were investigated following foliar $\mathrm{Zn}$ applications. Zinc uptake and redistribution between shoot and root were determined following application of six $\mathrm{Zn}$ doses to leaves. Twelve putative genes encoding proteins involved in $\mathrm{Zn}$ transport (MsZIP1-7, MsZIF1, MsMTP1, MsYSL1, MsHMA4, and MsNAS1) were identified and changes in their expression following Zn application were quantified using newly designed RT-qPCR assays. These assays are the first designed specifically for alfalfa and resulted in being more efficient than the ones already available for Medicago truncatula (i.e., MtZIP1-7 and MtMTP1). Shoot and root $\mathrm{Zn}$ concentration was increased following foliar $\mathrm{Zn}$ applications $\geq 0.1 \mathrm{mg}$ plant $^{-1}$. Increased expression of MsZIP2, MsHMA4, and MsNAS1 in shoots, and of MsZIP2 and MsHMA4 in roots was observed with the largest $\mathrm{Zn}$ dose $\left(10 \mathrm{mg} \mathrm{Zn} \mathrm{plant}^{-1}\right)$. By contrast, MsZIP3 was downregulated in shoots at $\mathrm{Zn}$ doses $\geq 0.1 \mathrm{mg}$ plant $^{-1}$. Three functional gene modules, involved in $\mathrm{Zn}$ uptake by cells, vacuolar $Z n$ sequestration, and $Z n$ redistribution within the plant, were identified. These results will inform genetic engineering strategies aimed at increasing the efficiency of crop Zn biofortification.

Keywords: ZIP transporters; nicotianamine; metal tolerance protein (MTP); yellow stripe-like protein (YSL); zinc-induced facilitators (ZIF); heavy metal transporters (HMA)

\section{Introduction}

A large proportion of the world's population suffers from Zn-related diseases (i.e., malabsorption syndrome, liver disease, chronic renal disease, sickle cell disease, and other chronic diseases), since they rely on cereal-based diets with low $\mathrm{Zn}$ content due to poor soil Zn availability [1-4]. Diversification of the human diet and biofortification of edible crops are therefore needed to alleviate Zn deficiency in humans. Similarly to humans, animals can suffer from $\mathrm{Zn}$ deficiencies that could be alleviated by biofortified feed or $\mathrm{Zn}$ supplementation, thus improving livestock health and quality of food products, which affect human health indirectly [5-8].

Zinc plays a major role as a co-factor of over 300 enzymes in plants and is an essential micronutrient [9]. Zinc is involved in various physiological functions, such as $\mathrm{CO}_{2}$ fixation, 
protein synthesis, free radical capture, regulation of growth and development, and disease resistance $[9,10]$. Many structural motifs in transcriptional regulatory proteins are stabilized by $\mathrm{Zn}$, such as $\mathrm{Zn}$ finger domains [11]. Zinc deficiency reduces crop production, as does $\mathrm{Zn}$ excess [12]. Excessive $\mathrm{Zn}^{2+}$ can compete with other cations in binding to enzymes and for transport across membranes, thereby impairing cellular activities [12]. Thus, the uptake of $\mathrm{Zn}^{2+}$ by cells and its transport within the plant must be strictly regulated. Plant cells have evolved several homeostatic mechanisms for avoiding $\mathrm{Zn}^{2+}$ toxicity when exposed to large $\mathrm{Zn}$ availability in their environment. These include the reduction of $\mathrm{Zn}$ influx to cells, the stimulation of $\mathrm{Zn}$ efflux from the cytosol, the sequestration of $\mathrm{Zn}$ in vacuoles, and the chelation of $\mathrm{Zn}$ by $\mathrm{Zn}$-binding ligands. In general, the concentration of $\mathrm{Zn}$ in plant tissues must be kept between 15 and $300 \mu \mathrm{g} \mathrm{Zn} \mathrm{g}{ }^{-1}$ dry matter (DM) to maintain cell structure and function [12,13]. Although tolerance to large tissue $\mathrm{Zn}$ concentrations varies among species [12,14], Zn concentrations above 400-500 $\mathrm{gg} \mathrm{g}^{-1} \mathrm{DM}$ often cause toxicity symptoms including impaired root and shoot growth, chlorosis and necrosis of leaves, reduced photosynthesis, nutrient imbalance, and ultimately loss of yield $[9,12,15,16]$.

The process of producing crops with greater mineral concentrations in edible tissues is called biofortification and provides a solution to the problem of mineral deficiencies in human and animal nutrition [17]. There are various approaches to Zn biofortification of edible crops, including agronomic strategies and conventional or transgenic breeding strategies. Agronomic biofortification aims to increase $\mathrm{Zn}$ concentrations in edible tissues through the application of $\mathrm{Zn}$ fertilizers to the soil or to leaves. It is relatively inexpensive and efficient [18]. Foliar application of $\mathrm{Zn}$ is generally more effective than the application of $\mathrm{Zn}$ fertilizers to soil, since $\mathrm{Zn}$ uptake by plant roots is often limited by the low solubility of $\mathrm{Zn}$ salts, its binding to organic substrates, and its immobilization in the microbial biomass [19]. Both agronomic and genetic biofortification strategies have been studied extensively in cereal staple crops, such as rice, wheat, and maize, but less in legumes, such as beans, peas, or lentils $[17,20,21]$. An international program, the HarvestPlus Zinc Fertilizer Project, is exploring the potential of $\mathrm{Zn}$ fertilizers to enhance the yields and $\mathrm{Zn}$ concentrations in edible portions of staple crops in developing countries of Africa, Asia, and South America (www.harvestzinc.org (accessed on 2 March 2021)) [22], but this program does not include forage crops.

The natural direction of $\mathrm{Zn}$ flux in plants is from the soil via roots to the shoot and seeds [23]. Various transport proteins and ligands that are responsible for $\mathrm{Zn}^{2+} \mathrm{up}-$ take by roots and its transport and sequestration within the plant have been characterized [12,24-26]. Among these, ZRT-IRT-like proteins (ZIPs) have been studied in several plants, including Arabidopsis thaliana, soybean (Glycine max), barley (Hordeum vulgare), barrel medic (Medicago truncatula), and rice (Oryza sativa) [27-31]. These proteins not only transport $\mathrm{Zn}^{2+}$ across membranes, but can also transport other transition metal cations, including $\mathrm{Cd}^{2+}, \mathrm{Fe}^{3+} / \mathrm{Fe}^{2+}, \mathrm{Mn}^{2+}, \mathrm{Ni}^{2+}, \mathrm{Co}^{2+}$, and $\mathrm{Cu}^{2+}[27,32,33]$. Generally, the expression of ZIP genes is upregulated when plants become Zn-deficient [34-36], facilitating Zn influx to cells and movement of $\mathrm{Zn}$ between organs, and also when plants become Feor Mn-deficient [35,37-39]. Other proteins that transport $\mathrm{Zn}$ include the metal tolerance proteins (MTPs), which function as cation/proton antiporters and are thought to transport $\mathrm{Zn}$ into vacuoles [40], and the yellow stripe-like proteins (YSLs), which transport the $\mathrm{Zn}$-nicotianamine complex (NA-Zn) and load Zn into the xylem and phloem [41]. The zinc-induced facilitators (ZIFs) and the heavy metal transporters (HMAs) are implicated in $\mathrm{Zn}$ influx to vacuoles and to the xylem, respectively [24]. Zinc is chelated by organic molecules, such as the carboxylic acid, citric acid, and nicotianamine (NA) in plants [42]. Nicotianamine is a non-proteinogenic amino acid with a high affinity for $\mathrm{Fe}, \mathrm{Cu}$, and $\mathrm{Zn}$, and is involved in their homeostasis [43]. Nicotianamine mediates the intercellular and interorgan movement of $\mathrm{Zn}$ and was found to enable $\mathrm{Zn}$ hyperaccumulation in Arabidopsis halleri and Noccaea caerulescens $[43,44]$. In general, the functions of these transporters have been studied by expressing them in yeast, but to understand how the various Zn transport proteins and chelates act together to maintain appropriate cytosolic and tissue $\mathrm{Zn}$ concen- 
trations, it is important to study the responses of an intact plant to fluctuations in Zn supply. Moreover, since there is a knowledge gap on the regulation of $\mathrm{Zn}$ transport following $\mathrm{Zn}$ foliar application, it is important also to elucidate plant transcriptional responses when $\mathrm{Zn}$ is not applied to roots.

Thus, in this study the transcriptional responses of genes encoding $\mathrm{Zn}$ transportrelated processes facilitating Zn uptake by cells, vacuolar sequestration, and redistribution within the plant were studied following foliar $\mathrm{Zn}$ application to the most productive and widely cultivated forage legume, alfalfa (Medicago sativa L.). The study was designed to provide information on the molecular responses to Zn biofortification of forage crops [7,45]. A model for the roles of putative genes encoding proteins involved in $\mathrm{Zn}$ transport- related processes was built and used for the selection of genes (Figure 1).

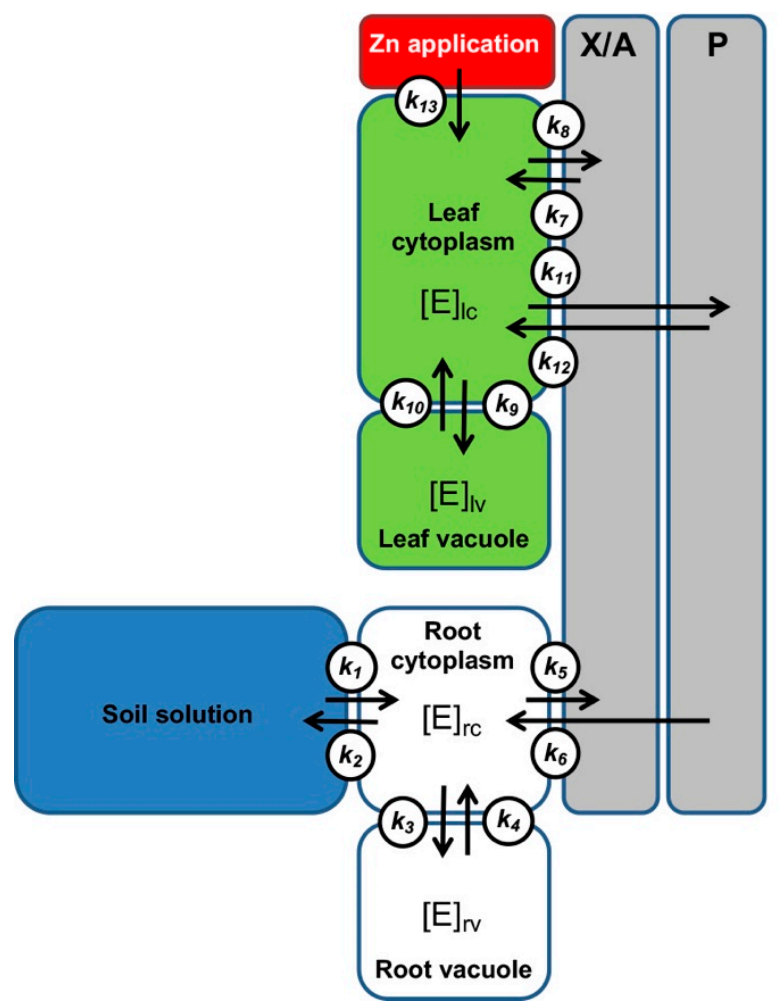

\begin{tabular}{|c|c|}
\hline Flux & Putative genes \\
\hline$k_{1}$ & $\begin{array}{c}M t Z I P 1[29], M t Z I P 4[29], M t Z I P 5[29], \\
\quad M t Z I P 6[29], M t(A t) Z I P 7[29,30]\end{array}$ \\
\hline$k_{2}$ & NAS1[46] \\
\hline$k_{3}$ & $\begin{array}{c}\text { NAS1[41,47], AtZIF1[48], } \\
\text { AtMTP1[49] }\end{array}$ \\
\hline$k_{4}$ & AtZIP1[30] \\
\hline$k_{5}$ & $\begin{array}{l}\text { NAS1[41,47], AtHMA4[50], } \\
\text { AtYSL1[41,51], MtZIP2[52] }\end{array}$ \\
\hline$k_{6}$ & $\begin{array}{c}\text { MtZIP1[29], Mt(Os)ZIP3[29,53], } \\
\text { MtZIP4[29], MtZIP5[29], MtZIP6[29], } \\
\text { Mt(At)ZIP7[29,30] }\end{array}$ \\
\hline$k_{7}$ & $\begin{array}{c}\text { MtZIP1[29], Mt(Os)ZIP3[29,53], } \\
\text { MtZIP4[29], MtZIP5[29], MtZIP6[29], } \\
\text { Mt(At)ZIP7[29,30] }\end{array}$ \\
\hline$k_{8}$ & AtHMA4[50], MtZIP2[52] \\
\hline$k_{9}$ & $\begin{array}{c}\text { NAS1[41,47], AtZIF1[48], } \\
\text { AtMTP1[49] }\end{array}$ \\
\hline$k_{10}$ & AtZIP1[30] \\
\hline$k_{11}$ & NAS1[41,47], AtYSL1[41,52] \\
\hline$k_{12}$ & $?$ \\
\hline$k_{13}$ & Free diffusion[54], stomata[54], ZIP? \\
\hline
\end{tabular}

Figure 1. Suggested model for roles of putative genes encoding proteins involved in $\mathrm{Zn}$ transport- related processes. The sites of action in the plant (i.e., root cytoplasm, rc; root vacuole, rv; xylem and apoplast, X/A; phloem, P; leaf cytoplasm, lc; leaf vacuole, lv) and the element $(E)$ fluxes $\left(\mathrm{K}_{1-13}\right)$ are reported. The concentration of the element is indicated in each site [E]. The scheme synthetizes information across studies in various plants. Gene abbreviations: ZIP, Zrt-/Irt-like protein; NAS, nicotianamine synthase; ZIF, zinc-induced facilitator; MTP, metal transporter protein; HMA, P1B-type heavy metal ATPase; YSL, yellow stripe like protein; ZIP? indicates a generic ZIP; free diffusion: diffusion through leaf epidermis; stomata: absorption through stomata. Plant abbreviations: Mt, Medicago truncatula; At, Arabidopsis thaliana; Os, Oryza sativa. References: [29,30,41,46-54].

The following hypotheses were tested: (i) foliar application of Zn determines Zn redistribution within the plant and is associated with changes in the expression of genes involved in Zn transport-related processes; (ii) genes encoding Zn transport-related processes are organized in functional modules that act in a concerted manner to redistribute $\mathrm{Zn}$ within the plant to maintain non-toxic cytosolic and tissue $\mathrm{Zn}$ concentrations. Genes encoding putative $\mathrm{Zn}$ transport-related processes were identified in alfalfa through phylogenetic comparisons and their likely roles are discussed. Changes in the expression of these genes following foliar $\mathrm{Zn}$ application were determined and the possible effects of these on the redistribution of $\mathrm{Zn}$ within cells and between tissues are also discussed. The knowledge gained from this study could help to optimize $\mathrm{Zn}$ biofortification strategies when using 
foliar $\mathrm{Zn}$ fertilizers and to provide strategies for breeding forage crops to addresses $\mathrm{Zn}$ deficiencies in livestock.

\section{Results}

2.1. Effects of Foliar Zn Application on Plant Zn Redistribution and Expression of Genes Involved in Zn Transport-Related Processes

The first aim of this study was to provide information on $\mathrm{Zn}$ redistribution within the plants and on the associated transcriptional responses of $\mathrm{Zn}$ transport-related genes following foliar $\mathrm{Zn}$ biofortification to alfalfa.

\subsubsection{Shoot and Root Zn Concentration and Content}

To provide novel information on $\mathrm{Zn}$ redistribution within alfalfa plants following foliar $\mathrm{Zn}$ application, we applied six $\mathrm{Zn}$ doses (0, 0.01, 0.1, 0.5, 1, $\left.10 \mathrm{mg} \mathrm{Zn} \mathrm{plant}^{-1}\right)$ and assessed $\mathrm{Zn}$ concentration and content in shoots and roots 5 days after application. The application of $\mathrm{Zn}$ to leaves did not modify shoot or root fresh and dry biomass (Table S1), and all M. sativa plants had a similar number of functional root nodules, irrespective of $\mathrm{Zn}$ treatments (data not shown). However, $\mathrm{Zn}$ concentrations in both shoots and roots were strongly affected by foliar $\mathrm{Zn}$ application $\left(\mathrm{F}_{(5,17)}=32.61, p<0.001 ; \mathrm{F}_{(5,17)}=28.53, p<0.001\right.$; respectively) (Figure 2a). A foliar $\mathrm{Zn}$ application of $0.01 \mathrm{mg} \mathrm{Zn} \mathrm{plant}{ }^{-1}$ produced a shoot $\mathrm{Zn}$ concentration similar to that of the control (no- $\mathrm{Zn}$ addition), but shoot $\mathrm{Zn}$ concentrations were increased progressively by larger doses $\left(0.1<0.5 / 1<10 \mathrm{mg} \mathrm{Zn} \mathrm{plant}^{-1}\right)$, from more than 3-fold to 35-fold more than that of the control (Figure 2). Foliar applications of 0.01,

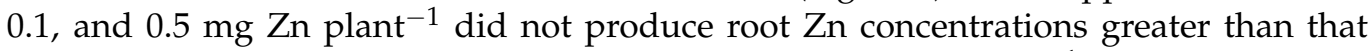
of the control treatment, but foliar doses of 1 and $10 \mathrm{mg} \mathrm{Zn} \mathrm{plant}^{-1}$ increased root $\mathrm{Zn}$ concentrations to 3-fold and 11-fold more than the control treatment, respectively. Shoot and root $\mathrm{Zn}$ contents were also strongly affected by foliar $\mathrm{Zn}$ application $\left(\mathrm{F}_{(5,17)}=53.73\right.$, $p<0.001 ; \mathrm{F}_{(5,17)}=32.45, p<0.001$; respectively) and their responses to increasing foliar $\mathrm{Zn}$ applications followed the corresponding $\mathrm{Zn}$ concentrations (Figure 2b). At all Zn dose plants did not show any visual symptom of Zn deficiency or toxicity. Moreover, plants grown for two months lacking $\mathrm{Zn}$ (i.e., $0 \mathrm{mg} \mathrm{Zn} \mathrm{plant}^{-1}$ ) had shoot and root $\mathrm{Zn}$ content of 4.5 and $2.7 \mu$ g plant $^{-1}$, respectively, probably relying on seed Zn content.

(a)

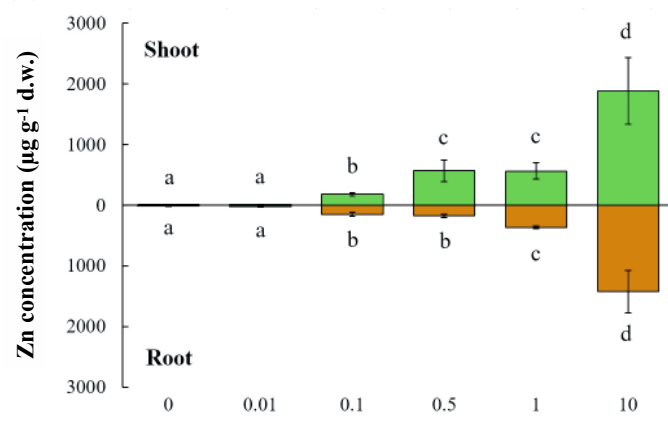

Dose of foliar $\mathrm{Zn}$ application (mg plant $\left.{ }^{-1}\right)$ (b)

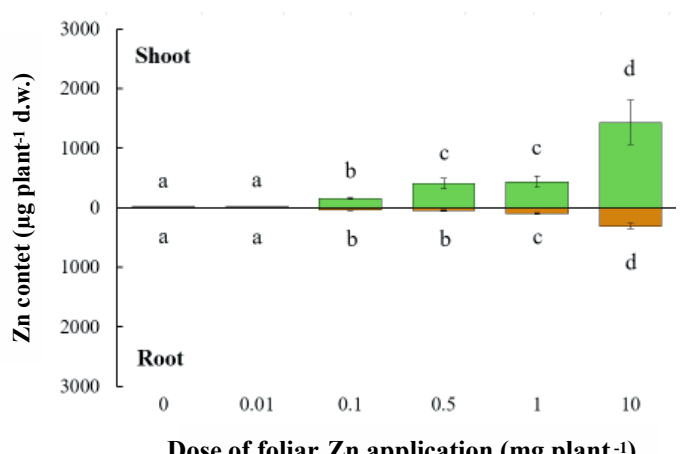

Figure 2. Zinc concentration (a) and content (b) in shoots and roots of alfalfa after the application of $\mathrm{Zn}$ to leaves. The $\mathrm{Zn}$ doses were $0,0.01,0.1,0.5,1$, or $10 \mathrm{mg} \mathrm{Zn} \mathrm{plant}^{-1}$. Means \pm standard error of three replicates are shown. Differences among the applied $\mathrm{Zn}$ doses were tested separately for shoot and root by one-way analysis of variance. Different letters denote significant differences in Zn concentrations in shoots and roots independently, according to Tukey-B honestly test $(p<0.05)$.

To summarize, the efficacy of $\mathrm{Zn}$ biofortification (i.e., shoot $\mathrm{Zn}$ concentrations in the range $15-400 \mu \mathrm{g} \mathrm{Zn} \mathrm{g}^{-1} \mathrm{~d}$.w.) was proved for the doses of 0.1 to $1 \mathrm{mg} \mathrm{plant}^{-1}$, while the lowest dose $\left(0.01 \mathrm{mg}\right.$ plant $\left.{ }^{-1}\right)$ was ineffective, and the highest dose $\left(10 \mathrm{mg} \mathrm{plant}^{-1}\right)$ produced toxic concentrations. 


\subsubsection{Phylogenetic Analysis}

To infer the putative roles of the selected M. sativa $\mathrm{Zn}$ transport-related genes, we performed phylogenetic analyses. This was based on the assumption of a simple equivalence between a minimum similarity threshold in the phylogenetic comparisons and the function similarity between encoded proteins. Phylogenetic analysis of the coding sequences of the ZIP genes revealed several distinct clades (Figure S1). One clade contained sequences for MsZIP2 and MsZIP7, which were similar to each other. In addition, the sequence of MsZIP2 was closely related to those of MtZIP2 and GmZIP1-ZIP2, and the sequence of MsZIP7 was closely related to those of $M t Z I P 7$ and AtZIP11. Another clade contained the sequences of MsZIP1, MsZIP3, MsZIP5, and MsZIP6. The sequence of MsZIP1 clustered with that of MtZIP1. Sequences of MsZIP3 and MsZIP5 were similar to each other and clustered with the corresponding sequences for M. truncatula genes (Figure S1). Sequences for MsZIP1, MsZIP3, and MsZIP5 were closely related to each other, whereas that of MsZIP6 formed a separate cluster with the sequences of MtZIP6 and AtZIP12. The sequence of MsZIP4 was distant from the sequences of other $M$. sativa ZIPs and formed a cluster with the sequences of MtZIP4 and AtZIP4.

Phylogenetic analyses of the coding sequences of the other genes related to $\mathrm{Zn}$ transport processes revealed that they were all similar to their $M$. truncatula counterparts. As regards ZIF, the sequence of MsZIF1 clustered with the sequences of MtZIF1 and GmZIF1 (Figure S2a). As regards MTP, the sequence of MsMTP1 formed a cluster with MtMTP1 and GMMTP1 and was also related to AtMTP1 and AtMTPA1 (Figure S2b). Similarly, the sequence of MsYSL1 was most similar to those of MtYSL1 and GmYSL1 (Figure S3a) and the sequence of MsHMA4 was most similar to those of MtHMA4 and GmHMA4 (Figure S3b). Finally, the sequence of MsNAS1 was closely related to those of MtNAS and GmNAS (Figure S4).

To summarize, the genes selected for gene expression analysis were closely related to the homologous of M. truncatula and of other plant species. Thus, on the basis of the pattern of clustering and of the functions described in literature for the encoded proteins, we were able to infer the putative roles of the genes.

\subsubsection{Gene Expression Analysis}

To provide novel information on the transcriptional responses of genes encoding $\mathrm{Zn}$ transport-related processes following foliar $\mathrm{Zn}$ application, we analyzed the expression of MsZIP1-7, MsMTP1, MsYSL1, MsHMA4, and MsNAS1 genes in shoots and roots, 5 days after $\mathrm{Zn}$ application of 0, 0.1, 1, and $10 \mathrm{mg} \mathrm{Zn} \mathrm{plant}{ }^{-1}$. The $\mathrm{Zn}$ treatments were selected on the basis of the significance of the results on $\mathrm{Zn}$ redistribution in shoots and roots. The expression of MsZIP3 was significantly downregulated only in shoots at foliar doses of 0.1, 1 , and $10 \mathrm{mg} \mathrm{Zn} \mathrm{plant}^{-1}\left(\mathrm{~F}_{(3,11)}=28.46, p<0.01\right)$ (Figure 3). By contrast, the expression of MsZIP2 was significantly upregulated in shoots and roots at the largest dose of $10 \mathrm{mg} Z \mathrm{Zn}$ plant $^{-1}\left(\mathrm{~F}_{(3,11)}=5.59, p<0.05 ; \mathrm{F}_{(3,11)}=9.26, p<0.01\right)$. The expression of MsZIP1, MsZIP5, and MsZIP6 in shoots was not significantly affected by foliar Zn application, although a general trend towards downregulation with increasing foliar $\mathrm{Zn}$ doses was observed. The expression of MsZIP4 and MsZIP7 in shoots was unaffected by foliar Zn application.

In roots, all ZIP genes except MsZIP2 were not significantly affected by foliar $\mathrm{Zn}$ application, although a general trend of MsZIP1, MsZIP3, MsZIP5, and MsZIP7 towards upregulation with increasing foliar $Z n$ doses was observed. Of the other genes related to $\mathrm{Zn}$ transport processes, the expression of MsHMA4 was significantly upregulated in both shoots $\left(\mathrm{F}_{(3,11)}=115.29, p<0.01\right)$ and roots $\left(\mathrm{F}_{(3,11)}=14.23, p<0.01\right)$ following the application of 1 and $10 \mathrm{mg} \mathrm{Zn} \mathrm{plant}{ }^{-1}$ (shoots: $+63 \%$ and $+424 \%$, respectively; roots: $+86 \%$ and $+66 \%$, respectively; Figure 4 ). 


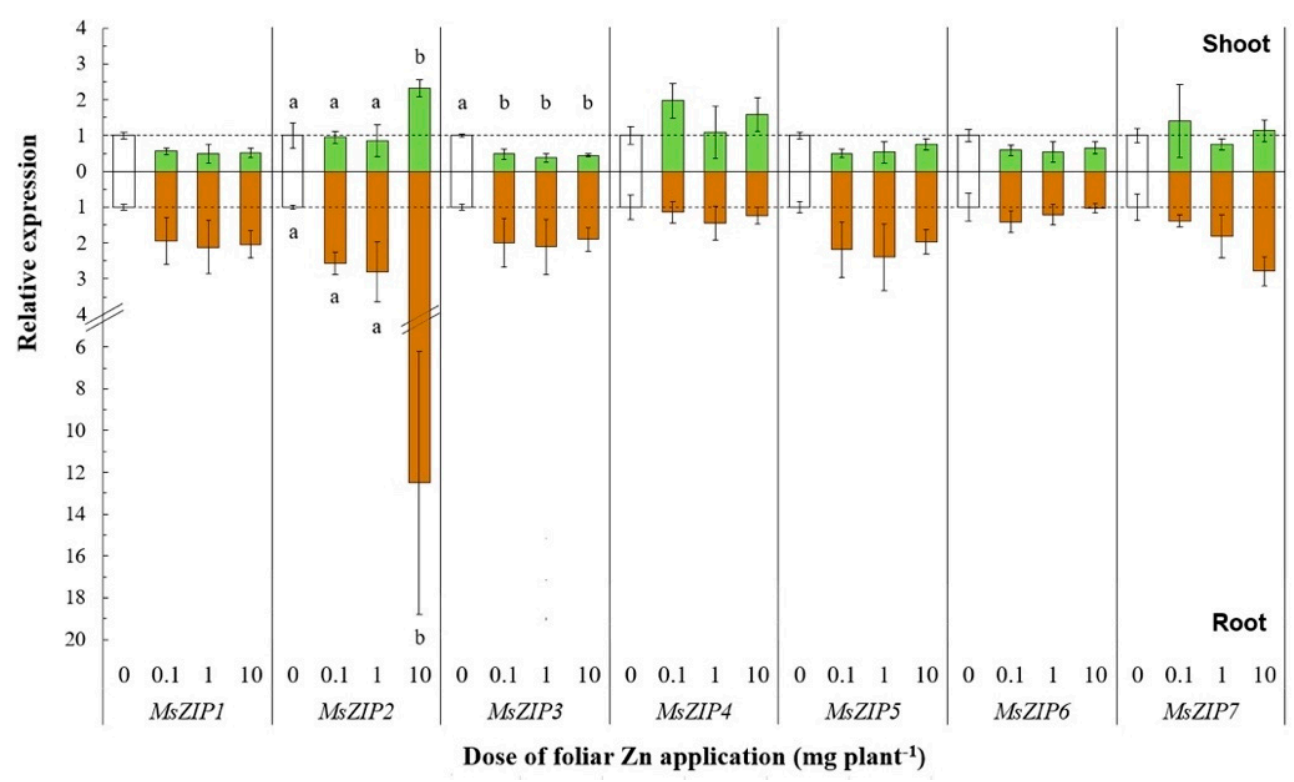

Figure 3. Relative expression of transmembrane $\mathrm{Zn}$ transporter genes after leaf $\mathrm{Zn}$ application to alfalfa. The $\mathrm{Zn}$ doses were $0,0.1,1$, or $10 \mathrm{mg} \mathrm{Zn} \mathrm{plant}^{-1}$. Means \pm standard error of three replicates are shown. The expression levels were calculated relative to reference genes (MsACT-101 for shoot and MsEF1- $\alpha$ for root) and to the control ( $\left.0 \mathrm{mg} \mathrm{Zn} \mathrm{plant}^{-1}\right)$. The broken line denotes the threshold between up- and downregulation relative to the control. Differences in the expressions of each gene after different $\mathrm{Zn}$ doses were tested separately for shoot and root by one-way analysis of variance. Different letters denote significant differences among Zn doses, according to Tukey-B test $(p<0.05)$.

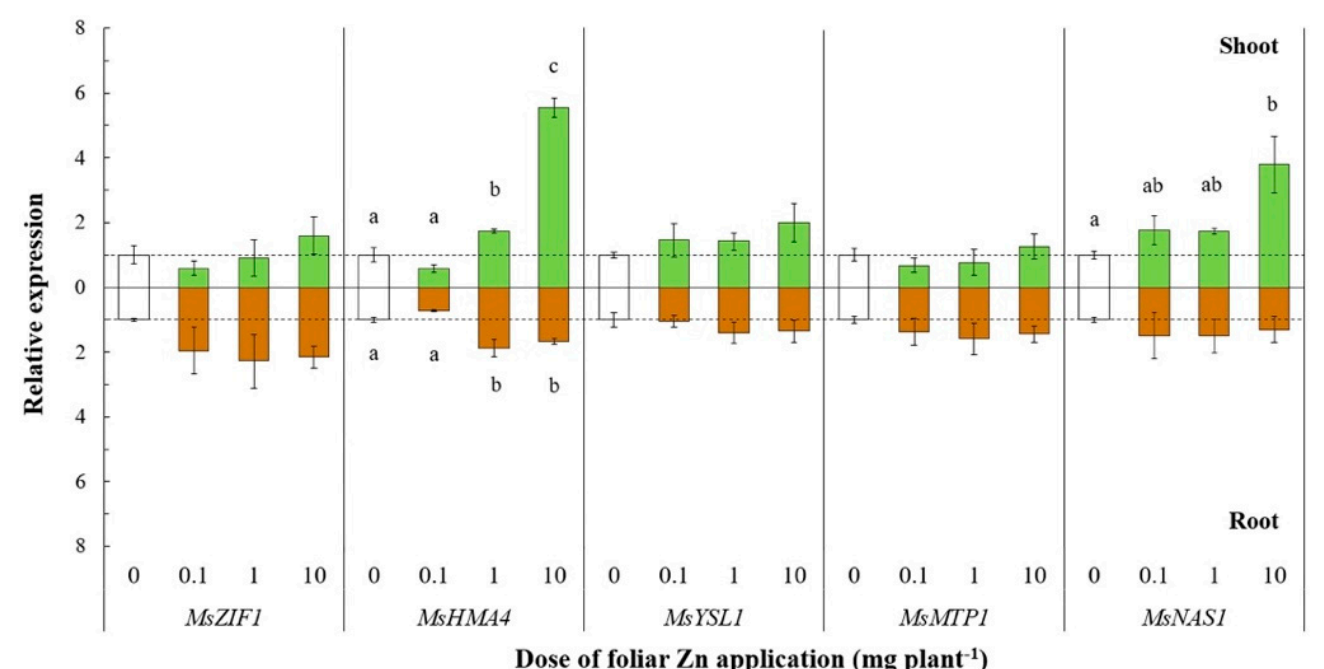

Figure 4. Relative expression of genes related to $\mathrm{Zn}$ transport processes after leaf $\mathrm{Zn}$ application to alfalfa. The $\mathrm{Zn}$ doses

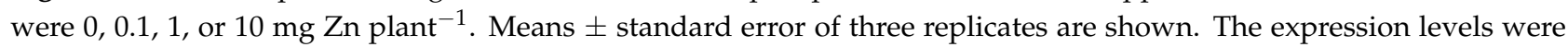
calculated relative to reference genes (MsACT-101 for shoot and MsEF1- $\alpha$ for root) and to the control ( $\left.0 \mathrm{mg} \mathrm{Zn} \mathrm{plant}^{-1}\right)$. The broken line denotes the threshold between up- and downregulation relative to the control. Differences in the expression of each gene at the different $\mathrm{Zn}$ doses were tested separately for shoot and root by one-way analysis of variance. Different letters denote significant differences among $\mathrm{Zn}$ doses, according to Tukey-B test $(p<0.05)$.

In shoots, the expression of MsHMA4 was about threefold higher following a dose of $10 \mathrm{mg} \mathrm{Zn} \mathrm{plant}{ }^{-1}$ than following a dose of $1 \mathrm{mg} \mathrm{Zn} \mathrm{plant}^{-1}$, whereas the expression of MsHMA4 in roots was similar when 1 or $10 \mathrm{mg} \mathrm{Zn} \mathrm{plant}^{-1}$ was applied.

The expression of MsNAS1 was also significantly upregulated $\left(\mathrm{F}_{(3,11)}=6.46, p<0.05\right)$ at the largest foliar $\mathrm{Zn}$ dose $\left(10 \mathrm{mg}_{\text {plant }}{ }^{-1}\right)$, whereas its expression in roots was unaltered following foliar Zn application (Figure 4). In shoots, MsYSL1 and MsZIF1 were not signifi- 
cantly affected by foliar $\mathrm{Zn}$ application, although there was a trend towards upregulation of the expression with increasing Zn doses, while the expression of MsMTP1 remained unaltered following the application of Zn (Figure 4). Finally, in roots, MsMTP1 and MsZIF1 were not significantly affected by foliar Zn application, although there was a trend towards upregulation of the expression with increasing Zn doses, whereas the expression of Ms YSL1 remained unchanged (Figure 4).

The permutation analysis of variance (PERMANOVA) showed that the expression of ZIP genes was significantly affected by foliar $\mathrm{Zn}$ application dose and differed between shoots and roots, which explained $29 \%$ and $23 \%$ of the total variance, respectively (Table 1 ). The expression of other genes related to Zn transport processes that were studied (MsZIF1, MsNAS1, MsHMA4, MsYSL1, and MsMTP1) were also affected by foliar Zn application dose and the organ examined. Zinc application dose explained $17 \%$ of the total variance, while plant organ explained 19\%. PERMANOVA on all studied genes highlighted a significant effect of $\mathrm{Zn}$ application dose, plant organ, and their interaction on gene expression, explaining $68 \%$ of the total variance.

Table 1. Permutation analyses of variance (PERMANOVAs) on the effect of application of three doses of zinc (Zn) (0.1, 1, and $10 \mathrm{mg} \mathrm{Zn} \mathrm{plant}^{-1}$ ) and plant compartment (shoot and root) on the expression of seven MsZIP genes and separately on the expression of other five genes (MsZIF1, MsNAS1, MsHMA4, MsYSL1, and MsMTP1). A PERMANOVA was also performed on the response of all the genes. The analysis of homogeneity of multivariate dispersion (PERMDISP) was also performed. The studied plant was alfalfa (Medicago sativa L.). The analysis also included no-Zn addition control.

\begin{tabular}{|c|c|c|c|c|c|}
\hline Response Variables & $\begin{array}{l}\text { Explanatory } \\
\text { Variables }\end{array}$ & Zn Application (Zn) & Plant Compartment (Comp) & Zn $\times$ Comp & Residual \\
\hline \multirow{4}{*}{ ZIP genes } & Pseudo F & 5.56 & 8.16 & 1.76 & \multirow{4}{*}{38.3} \\
\hline & $\mathrm{P}($ perm $)$ & 0.002 & 0.001 & 0.082 & \\
\hline & Explained variance (\%) & 29.1 & 22.9 & 9.7 & \\
\hline & PERMDISP P(perm) & 0.412 & 0.852 & & \\
\hline \multirow{4}{*}{ Other genes } & Pseudo F & 3.06 & 5.59 & 1.76 & \\
\hline & $\mathrm{P}($ perm $)$ & 0.007 & 0.015 & 0.1 & \\
\hline & Explained variance (\%) & 17.3 & 19.35 & 12.78 & \\
\hline & PERMDISP P(perm) & 0.412 & 0.852 & & \\
\hline \multirow{4}{*}{ All genes } & Pseudo F & 4.27 & 10.49 & 3.41 & \multirow{4}{*}{31.9} \\
\hline & $\mathrm{P}($ perm $)$ & 0.001 & 0.001 & 0.003 & \\
\hline & Explained variance (\%) & 17.3 & 25.2 & 25.6 & \\
\hline & PERMDISP P(perm) & 0.152 & 0.030 & & \\
\hline
\end{tabular}

To summarize, among the 12 studied genes, only the expression of MsZIP2, MsZIP3, MsHMA4, and MsNAS1 changed after foliar Zn application. MsZIP2 and MsHMA4 were upregulated in shoots and roots, whereas MsZIP3 was downregulated and MsNAS1 upregulated only in shoots.

\subsection{Functional Modules of Genes Encoding Zn Transport-Related Processes}

The second aim of this study was to provide novel information on how Zn transportrelated genes are organized in functional modules in alfalfa. Using correlation analysis to reveal functional modules of genes whose expression is co-regulated in plants, we observed three functional modules for co-expression (Figure $5 ; r>0.6$ ). The first functional module of genes consisted of MsZIP1, MsZIP5, and MsZIP6 in shoots and of MsZIP1, MsZIP3, MsZIP4, MsZIP5, and MsZIP6 in roots. The second functional module of genes consisted of MsMTP1 and MsZIF1 in both shoots and roots. The third functional module of genes consisted of MsHMA4, MsYSL1, and MsNAS1 in both shoots and roots. Moreover, while the expression pattern of ZIPs in shoots did not diverge from the one in roots, the expression pattern of the other genes involved in $\mathrm{Zn}$ transport-related processes strongly diverged (Figure 5). 
(a)

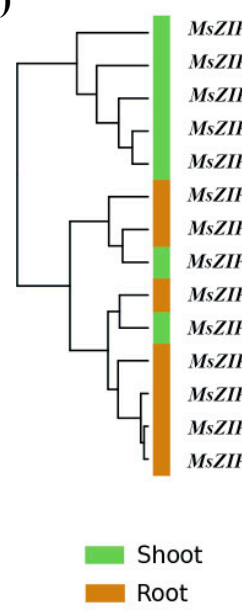

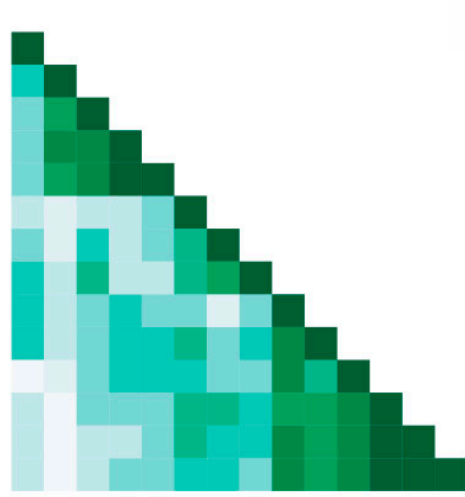

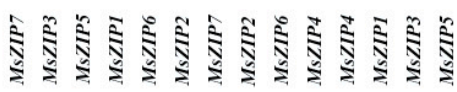

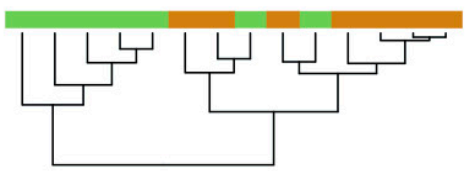

(b)
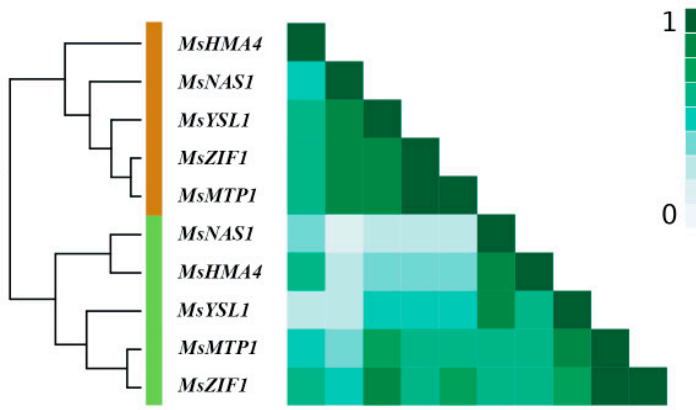

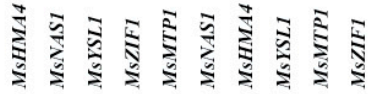

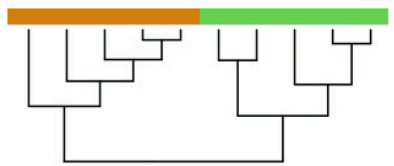

Figure 5. Heatmaps reporting correlations between expression of genes related to Zn transport after foliar Zn application. Gene expression is calculated as the difference between $0.1,1$, or $10 \mathrm{mg} \mathrm{Zn} \mathrm{plant}^{-1}$ and a control of $0 \mathrm{mg} \mathrm{Zn} \mathrm{plant}^{-1}$. The similarity in the degree of correlation in fold-change of gene expression to $\mathrm{Zn}$ application relative to the control was based on the average linkage clustering of the Pearson correlations $(r)$. In the clustering trees, the genes are indicated in brown for roots and in green for shoots, while the ranks of correlations of the heatmap are indicated by color intensity ( $r 0$ to 1 : from low to strong intensity of green). Seven genes encoding transmembrane Zn transporter (MsZIP1-7) (a); four genes encoding cellular Zn transporters (including vacuolar transporters) (MsZIF1, MsHMA4, MsYSL1, and MsMTP1) and a gene encoding a nicotianamine synthase (MsNAS1) (b).

The identification of these modules may allow for the definition of how the genes act in a concerted manner to redistribute $\mathrm{Zn}$ within the plant, maintaining non-toxic cytosolic and tissue $\mathrm{Zn}$ concentrations.

\section{Discussion}

In this work, for the first time, Zn biofortification was applied to the most productive and widely cultivated forage legume, alfalfa. Specific qPCR assays were designed for this crop and were successfully validated to study the gene expression response to foliar $\mathrm{Zn}$ application. We firstly characterized the expression of $\mathrm{Zn}$ transport-related genes after foliar $\mathrm{Zn}$ application to alfalfa and provide new molecular insights by identifying three functional gene modules involved in $\mathrm{Zn}$ influx to cells, $\mathrm{Zn}$ sequestration in the vacuole, and $\mathrm{Zn}$ redistribution within the plant.

\subsection{Zn Redistribution within the Plant after Foliar Zn Application}

The critical leaf concentration for Zn deficiency approximates $15-20 \mu \mathrm{g} \mathrm{Zn} \mathrm{g}{ }^{-1}$ dry weight and the critical leaf concentration for Zn toxicity approximates 400-500 $\mu \mathrm{g} \mathrm{Zn} \mathrm{g}^{-1}[12,13]$. Before foliar $Z n$ application, the alfalfa plants used in the experiments reported here were probably $\mathrm{Zn}$-deficient, since their shoot $\mathrm{Zn}$ concentrations were below the critical leaf concentration for $\mathrm{Zn}$ deficiency (Figure 2). After the application of the lowest foliar $\mathrm{Zn}$ dose $\left(0.01 \mathrm{mg}\right.$ plant $\left.^{-1}\right)$, plants probably remained Zn-deficient $\left(7.6 \mu \mathrm{g} \mathrm{Zn} \mathrm{g}{ }^{-1}\right.$ dry weight), but all other foliar $\mathrm{Zn}$ doses increased $\mathrm{Zn}$ concentrations in shoots above the critical concentration for Zn deficiency (Figure 2). Plants treated with $0.1 \mathrm{mg} \mathrm{Zn} \mathrm{plant}^{-1}$ probably had an optimal $\mathrm{Zn}$ status for plant growth, whereas plants treated with 0.5 and $1 \mathrm{mg} \mathrm{Zn} \mathrm{plant}{ }^{-1}$ had shoot $\mathrm{Zn}$ concentrations close to the toxicity threshold. When a foliar dose of $10 \mathrm{mg} \mathrm{Zn} \mathrm{plant}^{-1}$ was applied, shoot $\mathrm{Zn}$ concentrations greatly exceeding the threshold for $Z n$ toxicity (Figure 2). Plants often exhibit characteristic visual symptoms of $\mathrm{Zn}$ deficiency and $\mathrm{Zn}$ toxicity when these occur [12,13], but 5 days after foliar $\mathrm{Zn}$ 
application, no visual symptoms of Zn deficiency or toxicity, nor differences in plant biomass, were observed among plants receiving contrasting foliar $\mathrm{Zn}$ doses (data not

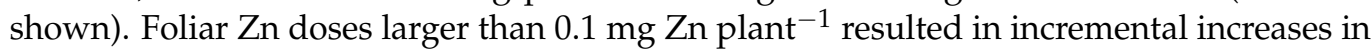
the $\mathrm{Zn}$ concentration and content of roots (Figure 2), despite $\mathrm{Zn}$ having limited mobility in the phloem [20,55]. This observation suggests that roots can act as a sink for $\mathrm{Zn}$ applied to leaves, thereby mitigating excessive $\mathrm{Zn}$ accumulation in shoot tissues.

In previous work, foliar application of $\mathrm{Zn}$ was shown to increase $\mathrm{Zn}$ concentration in phloem-fed tissues, such as fruits, seed, and tubers [56-59]. The shoot to root $\mathrm{Zn}$ concentration ratio shifted from values below one in conditions of Zn deficiency (0.4) to values greater than one in Zn-replete or Zn-intoxicated plants (1.3-3.2) (Figure 2). When the plants are $\mathrm{Zn}$-deficient, the recirculation of $\mathrm{Zn}$ between organs via the xylem and phloem is required to meet minimal growth demands and the application of foliar $\mathrm{Zn}$ to $\mathrm{Zn}$-deficient plants must be effectively redistributed within the plant $[42,60]$, whereas when excessive foliar $\mathrm{Zn}$ is applied, $\mathrm{Zn}$ must be chelated in the cytoplasm, sequestered in the vacuole, and redistributed via the phloem or xylem to other organs to avoid toxicity [12].

\subsection{Phylogenetic and Gene Expression Analysis}

Despite several genes encoding $\mathrm{Zn}$ transporters having been identified in plants, and the encoded proteins characterized, the mechanisms of $\mathrm{Zn}$ uptake and transport in alfalfa are still largely unknown. However, the recently sequenced alfalfa genome has allowed for the discovery of genes involved in $\mathrm{Zn}$ uptake and distribution within this species [61].

The influx and efflux of $\mathrm{Zn}$ across the plasma membrane of plant cells must be tightly controlled to allow optimal cell functioning and hence to ensure normal plant growth and development [42]. The expression of only two of the seven ZIP genes studied, MsZIP2 and MsZIP3, showed statistically significant responses to foliar Zn application (Figure 3). The expression of MsZIP2 was significantly upregulated in both shoots and roots in response to the largest dose of foliar $\mathrm{Zn}$ applied (10 mg Zn plant $\left.{ }^{-1}\right)$. It is likely that this dose is toxic to both shoot and root cells. The relative induction in the expression of MsZIP2 was greatest in roots. The phylogenetic analysis of ZIP transporters revealed that MsZIP2 is closely related to MtZIP2 and AtZIP2 (Figure S1). The AtZIP2 protein was previous found in the same clade with HsZIP2 [62]. Thus, MsZIP2 is probably located in the plasma membrane performing similar functions to MtZIP2, AtZIP2, and HsZIP2. The authors of [52] reported that $M$. truncatula plants grown with adequate soil $Z n$ availability expressed MtZIP2 in roots and stems, but not in leaves. The expression of MtZIP2 in roots increased with increasing $\mathrm{Zn}$ fertilizer applications to soil, with the greatest expression being found at toxic Zn doses [52]. Similarly, the authors of [30] found that the expression of AtZIP2 was $\approx 10$-fold higher in roots than shoots in Zn-replete Arabidopsis thaliana plants and that $\mathrm{Zn}$ deficiency reduced the expression of AtZIP2 in both roots and shoots. The localization of ZIP2 at the plasma membrane was observed in both M. truncatula [49] and A. thaliana [30]. The expression of AtZIP2 was localized to the stele of the root [30], supporting a role of AtZIP2 in long distance transport of $\mathrm{Zn}$ between roots and shoots. It is possible that the increased expression of MsZIP2 observed in our study when plants experience $\mathrm{Zn}$ toxicity might be a detoxification strategy, either through storing excess $\mathrm{Zn}$ in xylem parenchyma cells or recirculating $\mathrm{Zn}$ in the xylem.

The expression of MsZIP3 was significantly downregulated in shoots following the foliar application of Zn (Figure 3). The ZIP3 transporter is thought to mediate Zn influx to the cell from the apoplast [42]. Therefore, the downregulation of MsZIP3 in shoots of plants receiving more $\mathrm{Zn}$ is consistent with the ability of plant cells to control their $\mathrm{Zn}$ uptake to affect cytoplasmic $\mathrm{Zn}$ homeostasis. Reduced expression of MsZIP3 in plants with a greater Zn supply is also in agreement with previous studies of M. truncatula and A. thaliana [27,29], despite the higher phylogenetic similarity of MsZIP3 to MtZIP3 than to AtZIP3 (Figure S1). However, although AtZIP3 could restore growth to a Zn uptake-defective yeast [30], MtZIP3 was not found to be able to restore the growth of a $\mathrm{Zn}$ uptake-defective yeast in Zn-limited media, although it did restore the growth of a Fe uptake-defective yeast in 
Fe-limited media [29]. Thus, the MsZIP3 transporter could have a higher affinity for Fe than Zn. In O. sativa, the ZIP3 gene is expressed in the xylem parenchyma and transfer cells and might be responsible for unloading transition metal cations from the xylem to the parenchyma in plants receiving an excessive Zn supply [53]. The role of OsZIP3 in unloading $\mathrm{Zn}$ from the vascular tissues suggests that the reduced expression of MsZIP3 in shoots of $M$. sativa receiving an excessive foliar $\mathrm{Zn}$ dose might be a detoxification strategy to reduce $\mathrm{Zn}$ uptake by shoot cells.

The observation that foliar $\mathrm{Zn}$ applications had no effect on the expression of ZIP genes, except MsZIP2 and MsZIP3 (Figure 3), might be explained by the roles of ZIP proteins in the transport of other transition metals. For example, evidence of $\mathrm{Cu}$ and $\mathrm{Mn}$ transport by ZIP4 were provided through yeast complementation studies $[29,63]$. Moreover, applying the same technique, a role of ZIP6 was highlighted in the transport of Fe by [29], whereas the authors of [63] did not find any involvement of ZIP6 in the transport of $\mathrm{Cu}, \mathrm{Zn}$, or Fe. Although the changes in the expression of MsZIP1, MsZIP5, and MsZIP6 following foliar $\mathrm{Zn}$ application were not statistically significant, changes in their expression in shoots were positively correlated with changes in the expression of MsZIP3, showing a general trend for them to be downregulated following foliar $\mathrm{Zn}$ application and suggesting that these four ZIPs might act as a functional module in the shoot (Figure 5). By contrast, the expression of MsZIP1, MsZIP3, MSZIP4, and MsZIP5 were positively correlated in roots, suggesting that these genes behave as a functional module in roots.

The expression of MsHMA4, which is implicated in $\mathrm{Zn}$ redistribution within the plant [50-64], was increased in both shoots and roots of plants whose shoot Zn concentration suggested they were close to, or experiencing, $\mathrm{Zn}$ toxicity (Figure 4). The significant upregulation of MsHMA4 following foliar application of $\geq 1 \mathrm{mg} \mathrm{Zn} \mathrm{plant}{ }^{-1} \mathrm{might}_{\text {be }}$ related to the removal of excess $\mathrm{Zn}$ from both shoots and roots. This interpretation is consistent with the role of HMA4 in A. thaliana and in the metal hyperaccumulators Arabidopsis halleri and Noccea caerulescens [12,50,65-67], in which greater expression of HMA4 results in greater $\mathrm{Zn}$ flux to the xylem and $\mathrm{Zn}$ translocation to transpiring leaves. However, the phylogenetic similarity of MsHMA4 to MtHMA4 and, particularly, to AtHMA5 (Figure S3b) suggests a role in $\mathrm{Cu}$ transport [68-70]. The implication of the latter observation is unclear.

Since $\mathrm{Zn}^{2+}$ concentrations are low in the alkaline phloem sap, the transport of most $\mathrm{Zn}$ in the phloem is as $\mathrm{Zn}$ ligand complexes, such as zinc-nicotianamine (NA-Zn) [71]. Nicotianamine is the main $\mathrm{Zn}$ chelate in phloem transport and is also important for $\mathrm{Zn}$ sequestration in vacuoles [43], and tolerance of excessive Zn uptake [46]. Nicotianamine concentrations generally correlate with those of NAS transcripts, and for this reason NAS expression can be used as a proxy for NA content [48,72]. Accordingly, in the work reported here the increased expression of MsNAS1 in shoots following the application of $\geq 1 \mathrm{mg}$ Zn plant ${ }^{-1}$ (Figure 4) probably reflects the role of NA in Zn detoxification through its sequestration within vacuoles and its redistribution from shoot to root after excessive foliar $\mathrm{Zn}$ applications. This observation is consistent with the work of [71], who found that the expression of NAS2 in wheat increased following foliar $\mathrm{Zn}$ application, despite the high phylogenetic distance of the NAS genes in M. sativa and wheat (Figure S4). Moreover, other authors reported that $N A S$ expression is constitutively high in plants that hyperaccumulate Zn [12,72-74].

Homologs of MsMTP1 and MsZIF1 were previously found to encode transporters loading $\mathrm{Zn}$ and NA into the vacuoles of Thlaspi geosingense and A. thaliana cells, respectively $[48,75]$. Unexpectedly, the expression of these genes was unaffected by foliar $\mathrm{Zn}$ application (Figure 4). This observation suggests that the proteins encoded by these genes might not contribute to Zn detoxification in M. sativa. Nevertheless, only MsZIF1 of all the genes studied here showed a trend towards increased expression in roots with increasing foliar $\mathrm{Zn}$ dose, which might indicate a role in detoxification of excess $\mathrm{Zn}$ in roots through its sequestration with NA in the vacuole.

In A. thaliana, AtYSL1 has a role in the long-distance transport of the NA-Zn complex and in loading $\mathrm{Zn}$ into seeds $[41,76]$. For this reason and according to the similarities in 
the phylogenetic tree between MsYSL1/MtYSL1 and AtYSL1 (Figure S3a), an increase in the expression of $M t Y S L 1$ was expected to occur in parallel with the increased expression of MsNAS1 in shoots. However, the expression of MsYSL1 did not show any significant change in shoots or roots in response to foliar $\mathrm{Zn}$ application, although there was a trend towards greater MsYSL1 expression in shoots with increasing foliar Zn doses (Figure 4).

\subsection{Functional Modules of Genes Encoding Zn Transport-Related Processes}

The responses of gene expression to foliar $\mathrm{Zn}$ applications suggest three functional modules that effect cytoplasmic $\mathrm{Zn}$ homeostasis through $\mathrm{Zn}$ transport-related processes in M. sativa: genes involved in Zn influx to cells (shoots: MsZIP1, MsZIP5, and MsZIP6; roots: MsZIP1, MsZIP3, MSZIP4, MsZIP5, and MsZIP6), genes involved in Zn sequestration in the vacuole (shoots and roots: MsMTP1 and MsZIF1), and genes involved in Zn redistribution within the plant (shoots and roots: MsHMA4, MsYSL1, and MsNAS1) (Figure 5). In a previous work that jointly analyzed the structures and phylogenetic trees of 21 ZIP genes in Populus trichocarpa in response to metal stress, four classes of genes were identified [77]. Among them, class I and class II were identified as involved in the transportation and absorption of metal ions (i.e., Zn, iron, copper, and manganese) during nutritional surpluses, while class III and class IV were identified as induced for metal ion transport during stress. Similarly to our results, in PtrZIP1, PtrZIP4, PtrZIP5, and PtrZIP6 belonged to the same class (i.e., class I), but the pattern of gene expression under Zn deficiency and Zn application differed. Accordingly, a joint sequence and expression analysis of ZIP transporter genes revealed coexpression networks in iron acquisition strategies in land plants as well as in green algae [78].

The high correlation found in the present work between the expression of MsMTP1 and MsZIF1 in both shoots and roots (Figure 5) is also supported by previous works reporting a synergistic action of these gene for the sequestration of $\mathrm{Zn}$ in the vacuole $[48,75,79]$. Finally, the high correlation in the expression of MsHMA4, MsYSL1, and MsNAS1 found in shoots and roots in response to foliar $\mathrm{Zn}$ applications (Figure 5) supports the expectation that these genes are components of a functional module affecting the long-distance transport of $\mathrm{Zn}$ in the plant, as it was previously highlighted in A. thaliana by [80].

However, more effort should be made in further studies to verify the localization of those proteins within cell and tissue of $M$. sativa as well as of other known orthologs involved in $\mathrm{Zn}$ transport. Moreover, additional time course studies should be performed to account for time-dependent responses.

\section{Materials and Methods}

\subsection{Plant Growth and Experimental Design}

Surface-sterilized seeds of alfalfa (M. sativa L.) were germinated on moist sterilized silica sand (1-4 mm size) in a climatic chamber at $24 / 21^{\circ} \mathrm{C}$ day/night temperature, $16 / 18 \mathrm{~h}$ light/dark cycle, and $200 \mu \mathrm{mol}$ photons $\mathrm{m}^{-2} \mathrm{~s}^{-1}$. After 2 weeks of growth, 3 seedlings were transplanted to $1500 \mathrm{~mL}$ volume pots and filled with sterilized silica sand (number of pots 18), and Sinorhizobium meliloti was supplied as a filtrate to all plants to ensure that the plants produced nodules in all treatments. A Hoagland nutrient solution lacking Zn [81] was used to fertilize the plants, with $10 \mathrm{~mL}$ solution being applied every week. After 2 months of growth, when plants were in the vegetative growth stage, plants were treated with 1 of 6 doses of $\mathrm{Zn}\left(0,0.01,0.1,0.5,1\right.$, and $\left.10 \mathrm{mg} \mathrm{Zn} \mathrm{plant}^{-1}\right)$ (3 replicates per dose). Six $\mathrm{ZnSO}_{4} \cdot 7 \mathrm{H}_{2} \mathrm{O}$ solutions of $0,0.05,0.5,2.5,5$, and $50 \mathrm{~g} \mathrm{Zn} \mathrm{L}^{-1}$ were prepared to supply these doses. A drop of Tween 20 detergent was added to the 6 solutions to break the surface tension of the leaves and enhance Zn uptake. Zinc was applied to the middle leaf laminae of the 3 plants in each pot as twenty $10 \mu \mathrm{L}$ droplets. The experiment was arranged in a fully randomized design, with 3 replicates for each $\mathrm{Zn}$ dose. The shoots and roots of the plants were harvested separately 5 days after $\mathrm{Zn}$ application. At harvest, $1 \mathrm{mM} \mathrm{CaCl} 2$ solution and water were used to remove any residual $\mathrm{Zn}$ from the leaf surface [82]. Shoot 
and root fresh weight was measured, whereas shoot and root dry weight was determined on subsamples after oven drying at $70{ }^{\circ} \mathrm{C}$ to constant weight.

\subsection{Measurement of $\mathrm{Zn}$ Concentration}

Approximately $100 \mathrm{mg}$ of shoot or root dry biomass was carefully weighed and mineralized in a microwave medium pressure digestor (Milestone Start D, FKV Srl, Torre Boldone, Italy) with $7 \mathrm{~mL}$ of $69 \% \mathrm{HNO}_{3}$ and $2 \mathrm{~mL}$ of $30 \% \mathrm{H}_{2} \mathrm{O}_{2}$ (ultrapure grade). Zinc concentration in the resulting solutions was determined by inductively coupled plasma optical emission spectroscopy (ICP-OES) using an Optima 8000 spectrometer (Perkin Elmer, Waltham, MA, USA), following the procedure of [83].

\subsection{Gene Selection and Design and Validation of New RT-qPCR Assay}

Seven genes encoding putative ZRT-IRT-like proteins (ZIP) were selected for investigation (i.e., ZIP1-7) (Figure 1). The selection was based on information gathered by [29,52] on the expression of genes encoding $\mathrm{Zn}$ transporters in the model legume M. truncatula and on the structure of the neighbor-joining (NJ) tree built using available ZIP sequences of several plant species. Five more genes, whose products are involved in $\mathrm{Zn}$ transport-related processes [24], were also chosen for investigation on the basis of information gathered by other authors and on sequence similarity with other plant species. The NAS1 gene encoding nicotianamine synthase (NAS) was chosen because this enzyme synthesizes nicotianamine (NA), which is involved in long-distance $\mathrm{Zn}$ transport [41] (Figure 1). The HMA4 gene, which encodes a transmembrane P-type ATPase heavy metal transporter, was chosen because this transporter loads $\mathrm{Zn}$ into the xylem in roots for its transport to shoots [51] (Figure 1). The MTP1 gene, which encodes a transporter of the CDF family, was selected because this transporter is implicated in the sequestration of excess $\mathrm{Zn}$ in the vacuole [49,75] (Figure 1). The ZIF1 gene, which encodes the Zn-induced facilitator 1 transporter, was chosen because it transports NA into the vacuole to chelate vacuolar Zn $[48,84]$ (Figure 1). The YSL1 gene, which encodes a transporter of NA-Zn complexes, was chosen because it is implicated in $\mathrm{Zn}$ loading and transport of $\mathrm{Zn}$ in the phloem [60] (Figure 1). To standardize the expression of genes encoding $\mathrm{Zn}$ transport-related processes, we selected 2 reference genes: actin (ACT-101) and elongation factor 1- $\alpha$ (EF1- $\alpha)$ [85].

Using the draft genome sequence of alfalfa in the Alfalfa Gene Index and Expression Atlas Database (AEGD) [61] (http:/ / plantgrn.noble.org/AGED/index.jsp (accessed on 2 March 2021)), we retrieved homologous gene sequences of $M$. sativa by Basic Local Alignment Search Tool (BLAST) similarity searches using the gene sequences of M. truncatula. The chosen genes for M. sativa were named MsZIP1-7 for the seven ZIP genes and MsNAS1, MsHMA4, MsZIF1, MsYSL1, and MsMTP1 for the other selected genes. The two reference genes were named MsACT-101 and MsEF1- $\alpha$. The gene sequences and their annotations have been deposited in the National Center for Biotechnology Information (NCBI) under the submission \# 2338923.

Forward and reverse new PCR primers for the $12 \mathrm{Zn}$ transport-related genes and the 2 reference genes suitable for SYBR Green II RT-qPCR assays (Biorad, Hercules, CA, USA) were designed (Table 2). The Primer-BLAST online tool in the National Center for Biotechnology Information (NCBI; https:/ / www.ncbi.nlm.nih.gov/tools/primer-blast/ (accessed on 2 March 2021)) was used to design primers. The newly designed RT-qPCR assays are suitable for both M. sativa and M. truncatula. These assays are the first designed specifically for alfalfa and resulted to be more efficient than the ones already available for M. truncatula (i.e., MtZIP1-7 and MtMTP1; $[29,52,86])$. The length of the fragment, the Sanger sequences of the PCR amplicons (Table 1), and the single melting temperature peaks confirmed the specificity of the new RT-qPCR assays (Figure S5). Sanger sequencing was performed on PCR amplicons of 3 complementary DNA (cDNA) samples (Material and Methods S1). Examples of electropherograms of the sequences are reported in Figures S6 and S7. The sequences of the obtained PCR amplicons have been deposited in the NCBI under the submission \# 2338930. Amplification efficiencies (E) in the range of 
96.1-111.0\% were evidence of accurate quantification, while the coefficients of correlation $\left(R^{2}>0.998\right)$ indicated a high precision of measurements across concentration ranges of at least 3-4 orders of magnitude (Table 2 and Figure S8). The concentration ranges over which the relationship between the relative fluorescence and the logarithm of the concentration was linear, and the precision of quantification (standard curves) as reflected in the coefficient of correlation $\left(R^{2}\right)$, was determined using 3 independent 10 -fold serial dilutions of a cDNA sample of $M$. sativa. The accuracy of quantification was determined by the efficiency (E) of each qPCR amplification using the equation $E=\left[10^{-1 / S}-1\right] \times 100$, where $S$ is the slope of the standard curve. The evaluation of the reference genes based on the cycle threshold $(\mathrm{Ct})$ values made us choose the actin gene (MsACT-101) for quantifying relative gene expression in the shoots and the elongation factor 1- $\alpha(M s E F 1-\alpha)$ gene for quantifying relative gene expression in roots (Figure S9a,b). This choice was based on the observations that there was no statistical difference in the expression of the reference genes in tissues following foliar Zn applications and that MsACT-101 and MsEF1- $\alpha$ showed the smallest overall variation in the shoot and root, respectively (Figure $S 9 c, d)$.

\subsection{RNA Extraction and Gene Expression Analysis}

Total RNA was extracted from $50 \mathrm{mg}$ subsamples of fresh shoot and root tissue using the RNeasy Mini Kit (Qiagen, Hilden, Germany). The extractions were performed from tissues of plants treated with the foliar $\mathrm{Zn}$ doses that produced a significant increase in Zn concentration in shoots $\left(0.1,1\right.$, and $\left.10 \mathrm{mg} \mathrm{Zn} \mathrm{plant}^{-1}\right)$ and the control plants to which no foliar Zn had been applied (24 RNA extractions). Any DNA in the RNA extracts was removed by a DNase treatment (Promega, Madison, WI, USA). The purity of the RNA extracts was verified by spectroscopic light absorbance measurements at 230, 260, and $280 \mathrm{~nm}$ using the NanoDrop 2000 (Thermo Scientific, Worcester, MA, USA) [87]. The integrity and approximate concentration of the extracted RNA was determined by electrophoresis of the RNA extracts in a 1\% agarose gel containing Sybr Safe (Invitrogen, Carlsbad, CA, USA). One microgram of total RNA was reverse transcribed to complementary DNA (cDNA) using the iScript cDNA Synthesis Kit (Biorad, Hercules, CA, USA) in a $20 \mu \mathrm{L}$ reaction volume. The RT-qPCRs for gene expression analysis were run as 3 technical replicates with a final reaction volume of $20 \mu \mathrm{L}$, containing $10 \mu \mathrm{L}$ of SYBR Green Supermix (Biorad, Hercules, CA, USA), $5 \mu \mathrm{L}$ of 100-fold diluted cDNA, and $0.4 \mu \mathrm{M}$ final concentrations of the gene-specific PCR primers on a CFX Connect Real-Time System thermal cycler (Biorad, Hercules, California). The qPCR conditions were $95^{\circ} \mathrm{C}$ for $3^{\prime}$, followed by 40 cycles of $95^{\circ} \mathrm{C}$ for $5^{\prime}$, and $60{ }^{\circ} \mathrm{C}$ for $30^{\prime \prime}$. A dissociation curve of each reaction was performed $\left(65^{\circ} \mathrm{C}\right.$ to $95^{\circ} \mathrm{C}, 0.5^{\circ} \mathrm{C}$ increment every $\left.5^{\prime \prime}\right)$ to check that PCR amplified only one product. The most suitable reference gene for relative gene expression analysis was determined by comparing the expression levels of the reference genes MsACT-101 and MsEF1- $\alpha$ across all cDNA samples. Relative gene expression was calculated using the double standardization $(\Delta \Delta \mathrm{Cq})$ method that requires a reference gene and a control treatment [88]. 


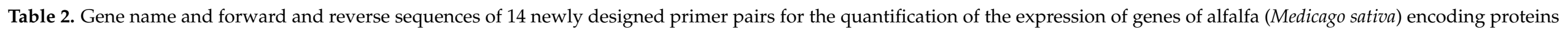

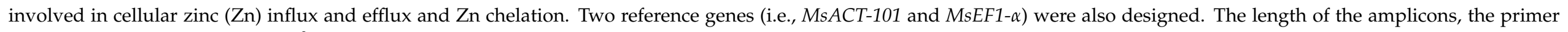

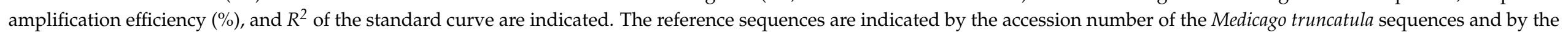

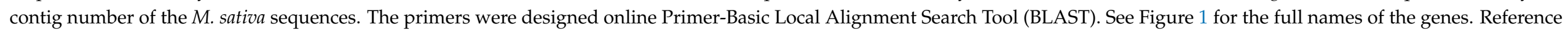

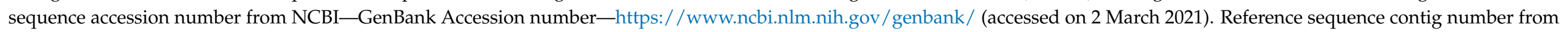
AGED—The Alfalfa Gene Index and Expression Atlas Database—http:/ / plantgrn.noble.org/AGED/ (accessed on 2 March 2021).

\begin{tabular}{|c|c|c|c|c|c|c|}
\hline Gene* & $\begin{array}{c}\text { Reference Sequence Accession } \\
\text { Number and Contig Number }\end{array}$ & $\begin{array}{c}\text { Forward Primer } \\
\left(5^{\prime}-3^{\prime}\right)\end{array}$ & $\begin{array}{c}\text { Reverse Primer } \\
\qquad\left(5^{\prime}-3^{\prime}\right)\end{array}$ & Amplicon Size (bp) & Efficiency (\%) & $R^{2}$ \\
\hline MsZIP1 & AY339054 $4^{\dagger} / 19855^{\ddagger}$ & ATGATTAAAGCCTTCGCGGC & TCTGCTGGAACTTGTTTAGAAGG & 233 & 99.8 & 0.999 \\
\hline MsZIP2 & AY007281/82450 & AGCCCAATTGGCGTAGGAAT & ACAGCAACACCAAAAAGCACA & 215 & 99.3 & 0.999 \\
\hline MsZIP3 & AY339055/33860 & TGGTGTGATTTTGGCAACCG & TGACGGACCCGAAGAAACAG & 325 & 104.9 & 0.999 \\
\hline MsZIP4 & XM_003603101/92651 & GGAGGGTGCATTTCTCAAGC & AGCAATGCCTGTTCCAATGC & 108 & 97.1 & 0.999 \\
\hline MsZIP5 & XM_013605712/66451 & TGAAGGCATGGGACTTGGAA & CCAGCTGAAGCTGCATTGAA & 192 & 99.3 & 0.998 \\
\hline MsZIP7 & AY339059/62098 & GGCTTGTGCTGGTTATTTGAT & TTTCCATGCGTCTGCTTTTGT & 310 & 96.1 & 0.999 \\
\hline MsZIF1 & XM_003601836/59165 & TGCCTGCATTTGGTTACCG & CTGCAGCTTCCACATTGTCAG & 77 & 105.9 & 0.999 \\
\hline MsHMA4 & XM_003626900/19210 & TGCTCAACTTGCCAAAGCAC & GGAATGAACCATCCCAGCCA & 111 & 108.9 & 0.999 \\
\hline MsYSL1 & XM_024781439/4892 & CAAGAAGCAAGTGCATGGGT & TCCACAGTCTTCTTTGCCTGAG & 94 & 111.0 & 0.999 \\
\hline MsMTP1 & FJ389717/67347 & TGCAGCATTTGCCATCTCCT & TGCATAGAAACCAAAGCACCA & 114 & 104.5 & 0.999 \\
\hline MsNAS1 & XM_003594705/61146 & GCTAGCTTGGCTGAAGATTGG & AGATACAAAGCACTCGGAGACA & 87 & 100.5 & 0.999 \\
\hline$M s E F 1-\alpha$ & XM_003618727/56897 & CCACAGACAAGCCCCTCAG & TCACAACCATACCGGGCTTC & 114 & 100.2 & 0.999 \\
\hline
\end{tabular}

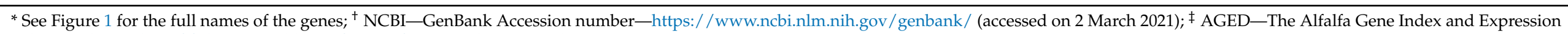
Atlas Database-http:// plantgrn.noble.org/AGED/ (accessed on 2 March 2021). 


\subsection{Bioinformatic and Statistical Analyses}

A BLAST search was performed in the Alfalfa Gene Index and Expression Atlas database using the ZIP1-7, ZIF1, MTP1, YSL1, HMA4, and NAS coding sequences from M. truncatula. This allowed for the identification of gene sequences encoding potential metal transporters and chelators in the whole $M$. sativa genome. The sequences obtained were aligned with the corresponding sequences from M. truncatula, and the length of the $M$. sativa genes was determined after removing the external unaligned nucleotides. The M. sativa and M. truncatula ZIP gene sequences were also aligned with those of other plant species (A. thaliana, G. max, H. vulgare, O. sativa, Triticum aestivum, and Zea mays) obtained from a search of GenBank. Similarly, the M. sativa and M. truncatula gene sequences of ZIF1, MTP1, YSL1, HMA4, and NAS were aligned with their corresponding sequences of other plant species (A. thaliana, G. max, H. vulgare, O. sativa, T. aestivum, and Z. mays) obtained from a search of GenBank. Sequence alignments were performed using the algorithm ClustalW in MEGA X [89]. Phylogenetic comparisons were performed to infer the putative roles of the selected $M$. sativa $\mathrm{Zn}$ transport-related gens. This was based on the assumption of a simple equivalence between a minimum similarity threshold in the phylogenetic comparisons and the function similarity between encoded proteins. For some proteins belonging to the same family, this assumption can hold true, since they have been shown to have very tightly correlating functions, such as those considered in this study. Thus, functions are indicated with high probability by annotations based on similarities. The phylogenetic trees were inferred by neighbor-joining (NJ) analysis [90] in MEGA X, and the evolutionary distances were calculated using the p-distance method [91]. Branch support bootstrap values were derived from 500 bootstrap replicates. The phylograms were drawn by MEGA X and edited using Adobe Illustrator CC 2017.

The effect of the application of the foliar $\mathrm{Zn}$ on tissue $\mathrm{Zn}$ concentration and on the expression of the selected genes was analyzed in shoots and roots separately by one-way analysis of variance (ANOVA), followed by a Tukey-B test in the case of significance of the response to foliar $\mathrm{Zn}$ application. When required, gene expression data were logtransformed to meet the ANOVA assumptions. The data displayed graphically are the means and associated standard errors of the untransformed raw data. All statistical analyses were performed using the software package SPSS version 21.0 (SPSS Inc., Chicago, IL, USA). Permutational analysis of variance (PERMANOVA) [92] was used to test the effect of foliar $\mathrm{Zn}$ application and plant organ (shoot and root) on the expression of the 7 ZIP genes and of the other 5 genes encoding Zn transport-related processes separately. In addition, the PERMANOVA was performed on the expression of all the genes together. The response data matrices were standardized by sample and total, and then Euclidean distances were calculated among samples. $P$-values were calculated using the Monte Carlo test [93]. Since PERMANOVA is sensitive to differences in multivariate location and dispersion, analysis of homogeneity of multivariate dispersion (PERMDISP [94]) was performed to check the homogeneity of dispersion among groups. The analyses were performed using PRIMER 7 and PERMANOVA+ software [95]. Finally, heatmaps were constructed to illustrate correlations in expression among ZIPs and among other genes encoding $\mathrm{Zn}$ transport-related processes using the R package ggplot2 [96], using the average linkage clustering of the Pearson correlations calculated from relative gene expression following foliar $\mathrm{Zn}$ application.

\section{Conclusions}

This is the first study to characterize the expression of genes related to $\mathrm{Zn}$ transport processes following foliar $\mathrm{Zn}$ application to a forage legume, providing new molecular insights to the responses of $\mathrm{Zn}$ transport-related processes to foliar $\mathrm{Zn}$ applications. A significant increase in the expression of MsZIP2 as foliar Zn doses increased suggests the detoxification of excess $\mathrm{Zn}$ through the accumulation of $\mathrm{Zn}$ in xylem parenchyma cells. A decrease in the expression of MsZIP3 as foliar Zn doses increased suggests a reduction in the $\mathrm{Zn}$ influx capacity of shoot cells to reduce $\mathrm{Zn}$ uptake. An increase in the expression 
of MsHMA4 in roots and shoots as foliar $\mathrm{Zn}$ doses increased suggests an increase in the transport of $\mathrm{Zn}$ in the xylem when plants are subject to $\mathrm{Zn}$ toxicity, while an increase in the expression of MsNAS1 in the shoot suggests the chelation of excess $\mathrm{Zn}$ in the shoot, enabling $\mathrm{Zn}$ sequestration in vacuoles or the redistribution of $\mathrm{Zn}$ to roots via the phloem. The elucidation of three functional modules of genes involved in (a) Zn influx to cells, (b) sequestration of $\mathrm{Zn}$ in the vacuole, and (c) redistribution of $\mathrm{Zn}$ within the plant are fundamental to understanding the molecular mechanisms of cytoplasmic Zn homeostasis and might inform the selection of appropriate genotypes enabling greater $\mathrm{Zn}$ accumulation in edible portions or increased tolerance of $\mathrm{Zn}$ in the environment.

Supplementary Materials: The following are available online at https:/ / www.mdpi.com/2223-774 7/10/3/476/s1: Figure S1: Neighbor-joining (NJ) phylogenetic tree of ZIP gene sequences of alfalfa and other plant species. Figure S2: NJ phylogenetic trees of ZIF and MTP genes sequences ((a) and (b), respectively) of alfalfa and other plant species. Figure S3: NJ phylogenetic trees of YSL and HMA gene sequences ((a) and (b), respectively) of alfalfa and other plant species. Figure S4: NJ phylogenetic trees of NAS gene sequences of alfalfa and other plant species. Figure S5: Melting curve analysis of PCR products. Figure S6: Examples of electropherograms of PCR products of ZIP genes (MsZIP1-7). Figure S7: Examples of electropherograms of PCR products of the genes MsZIF1, MsHMA4, MsYSL1, MsNAS1, and MsMTP1 and of the reference genes MsACT-101 and MsEF1- $\alpha$. Figure S8: Standard curves for the 14 newly designed primer pairs. Figure S9: Cycle threshold value of the reference genes. Table S1: Fresh and dry weight of shoots and roots of alfalfa after leaf $\mathrm{Zn}$ application. Material and methods S1: PCR details.

Author Contributions: Conceptualization, E.P. and L.E.; methodology, A.C., E.P., and L.E.; validation A.C. and B.M.; formal analysis, A.C. and M.C.M.; investigation, A.C., E.P., and L.E.; data curation, A.C. and E.P.; Writing-Original draft preparation, A.C., E.P., and L.E.; Writing-Review and editing, A.C., E.P., P.J.W., and L.E.; funding acquisition, L.E. All authors have read and agreed to the published version of the manuscript.

Funding: This research received no external funding.

Data Availability Statement: The gene sequences and their annotations have been deposited in the NCBI under the submission \# 2338923. The sequences of the obtained PCR amplicons have been deposited in the NCBI under the submission \# 2338930.

Acknowledgments: We acknowledge Hannes A. Gamper for the technical support in real-time RT-PCR.

Conflicts of Interest: The authors declare no conflict of interest.

\section{References}

1. Prasad, A.S. Discovery of human zinc deficiency: Its impact on human health and disease. Adv. Nutr. 2013, 4, 176-190. [CrossRef]

2. Cakmak, I.; McLaughlin, M.J.; White, P. Zinc for better crop production and human health. Plant Soil 2017, 411, 1-4. [CrossRef]

3. Koren, O.; Tako, E. Chronic dietary zinc deficiency alters gut microbiota composition and function. Multidiscip. Digital Publ. Inst. Proc. 2020, 61, 16. [CrossRef]

4. Desta, M.K.; Broadley, M.R.; McGrath, S.P.; Hernandez-Allica, J.; Hassall, K.L.; Gameda, S.; Amede, T.; Haefele, S.M. Plant vailable zinc is influenced by landscape position in the Amhara region, Ethiopia. Plants 2021, 10, 254. [CrossRef]

5. McDonald, P.; Edwards, R.A.; Greenhalgh, J.F.D.; Morgan, C.A. Animal Nutrition; Pearson Education Limited: Harlow, UK, 2002.

6. Ciccolini, V.; Pellegrino, E.; Coccina, A.; Fiaschi, A.I.; Cerretani, D.; Sgherri, C.; Quartacci, M.F.; Ercoli, L. Biofortification with iron and zinc improves nutritional and nutraceutical properties of common wheat flour and bread. J. Agric. Food Chem. 2017, 65, 5443-5452. [CrossRef] [PubMed]

7. Capstaff, N.M.; Miller, A.J. Improving the yield and nutritional quality of forage crops. Front. Plant Sci. 2018, 9, 1-18. [CrossRef] [PubMed]

8. Huma, Z.E.; Khan, Z.I.; Noorka, I.R.; Ahmad, K.; Bayat, A.R.; Wajid, K. Bioaccumulation of zinc and copper in tissues of chicken fed corn grain irrigated with different water regimes. Int. J. Environ. Res. 2019, 13, 689-703. [CrossRef]

9. Broadley, M.R.; White, P.J.; Hammond, J.P.; Zelko, I.; Lux, A. Zinc in plants. New Phytol. 2007, 173, 677-702. [CrossRef]

10. Sasaki, H.; Hirose, T.; Watanabe, Y.; Ohsugi, R. Carbonic anhydrase activity and $\mathrm{CO}_{2}$-transfer resistance in $\mathrm{Zn}$-deficient rice leaves. Plant Physiol. 1998, 118, 929-934. [CrossRef]

11. Albert, I.L.; Nadassy, K.; Wodak, S.J. Analysis of zinc binding sites in protein crystal structures. Protein Sci. 1998, 7, 1700-1716. [CrossRef]

12. White, P.J.; Pongrac, P. Heavy-metal toxicity in plants. In Plant Stress Physiology; CABI: Wallingford, UK, 2017 ; pp. 301-331. 
13. Broadley, M.R.; Brown, P.; Cakmak, I.; Rengel, Z.; Zhao, F. Function of nutrients: Micronutrients. In Marschner's Mineral Nutrition of Higher Plants; Academic Press: London, UK, 2012; pp. 191-248.

14. Alloway, B.J. Zinc in Soils and Crop Nutrition; IZA and IFA: Brussels, Belgium; Paris, France, 2008.

15. Chaney, R.L. Zinc phytotoxicity. In Zinc in Soils and Plants; Springer: Dordrecht, The Netherlands, $1993 ;$ pp. 135-150.

16. Di Baccio, D.; Tognetti, R.; Minnocci, A.; Sebastiani, L. Responses of the Populus x euramericana clone I-214 to excess zinc: Carbon assimilation, structural modifications, metal distribution and cellular localization. Environ. Exp. Bot. 2009, 67, 153-163. [CrossRef]

17. White, P.J.; Broadley, M.R. Biofortifying crops with essential mineral elements. Trends Plant Sci. 2005, 10, 586-593. [CrossRef]

18. Saltzman, A.; Birol, E.; Bouis, H.E.; Boy, E.; De Moura, F.F.; Islam, Y.; Pfeiffer, W.H. Biofortification: Progress toward a more nourishing future. Glob. Food Secur. 2013, 2, 9-17. [CrossRef]

19. Gregory, P.J.; Wahbi, A.; Adu-Gyamfi, J.; Heiling, M.; Gruber, R.; Joy, E.J.M.; Broadley, M.R. Approaches to reduce zinc and iron deficits in food systems. Glob. Food Secur. 2017, 15, 1-10. [CrossRef]

20. White, P.J.; Broadley, M.R. Physiological limits to zinc biofortification of edible crops. Front. Plant Sci. 2011, 2, 80. [CrossRef]

21. Rawat, N.; Neelam, K.; Tiwari, V.K.; Dhaliwal, H.S. Biofortification of cereals to overcome hidden hunger. Plant Breeding 2013, 132, 437-445. [CrossRef]

22. Cakmak, I. HarvestPlus zinc fertilizer project: HarvestZinc. Better Crops 2012, 96, 17-19.

23. White, P.J.; Broadley, M.R. Biofortification of crops with seven mineral elements often lacking in human diets-iron, zinc, copper, calcium, magnesium, selenium and iodine. New Phytol. 2009, 182, 49-84. [CrossRef] [PubMed]

24. Olsen, L.I.; Palmgren, M.G. Many rivers to cross: The journey of zinc from soil to seed. Front. Plant Sci. 2014, 5, 30. [CrossRef]

25. Caldelas, C.; Weiss, D.J. Zinc homeostasis and isotopic fractionation in plants: A review. Plant Soil 2017, 411, 17-46. [CrossRef]

26. Hacisalihoglu, G. Zinc ( $\mathrm{Zn})$ : The last nutrient in the alphabet and shedding light on $\mathrm{Zn}$ efficiency for the future of crop production under suboptimal zn. Plants 2020, 9, 1471. [CrossRef] [PubMed]

27. Grotz, N.; Fox, T.; Connolly, E.; Park, W.; Guerinot, M.L.; Eide, D. Identification of a family of zinc transporter genes from Arabidopsis that respond to zinc deficiency. Proc. Natl. Acad. Sci. USA 1998, 95, 7220-7224. [CrossRef] [PubMed]

28. Zhao, H.; Eide, D. The yeast ZRT1 gene encodes the zinc transporter protein of a high-affinity uptake system induced by zinc limitation. Proc. Natl. Acad. Sci. USA 1996, 93, 2454-2458. [CrossRef] [PubMed]

29. López-Millán, A.F.; Ellis, D.R.; Grusak, M.A. Identification and characterization of several new members of the ZIP family of metal ion transporters in Medicago truncatula. Plant Mol. Biol. 2004, 54, 583-596. [CrossRef]

30. Milner, M.J.; Seamon, J.; Craft, E.; Kochian, L.V. Transport properties of members of the ZIP family in plants and their role in Zn and Mn homeostasis. J. Exp. Bot. 2013, 64, 369-381. [CrossRef]

31. Tiong, J.; McDonald, G.; Genc, Y.; Shirley, N.; Langridge, P.; Huang, C.Y. Increased expression of six ZIP family genes by zinc (Zn) deficiency is associated with enhanced uptake and root-to-shoot translocation of Zn in barley (Hordeum vulgare). New Phytol. 2015, 207, 1097-1109. [CrossRef] [PubMed]

32. Mäser, P.; Thomine, S.; Schroeder, J.I.; Ward, J.M.; Hirsch, K.; Sze, H.; Talke, I.N.; Amtmann, A.; Maathuis, F.J.M.; Sanders, D.; et al. Phylogenetic relationship within cation transporter families of Arabidopsis. Plant Physiol. 2001, 126, 1646-1667. [CrossRef]

33. Eckhardt, U.; Marques, A.M.; Buckhout, T.J. Two iron-regulated cation transporters from tomato complement metal uptakedeficient yeast mutants. Plant Mol. Biol. 2001, 45, 437-448. [CrossRef]

34. Ramesh, S.A.; Shin, R.; Eide, D.J.; Schachtman, D.P. Differential metal selectivity and gene expression of two zinc transporters from rice. Plant Physiol. 2003, 133, 126-134. [CrossRef]

35. Ishimaru, Y.; Suzuki, M.; Tsukamoto, T.; Suzuki, K.; Nakazono, M.; Kobayashi, T.; Wada, Y.; Watanabe, S.; Matsuhashi, S.; Nakanishi, H.; et al. Rice plants take up iron as an Fe3p-phytosiderophore and as Fe2p. Plant J. 2006, 45, 335-346. [CrossRef]

36. Eide, D.; Broderius, M.; Fett, J.; Guerinot, M.L. A novel iron-regulated metal transporter from plants identified by functional expression in yeast. Proc. Natl. Acad. Sci. USA 1996, 93, 5624-5628. [CrossRef] [PubMed]

37. Bughio, N.; Yamaguchi, H.; Nishizawa, N.K.; Nakanishi, H.; Mori, S. Cloning an iron-regulated metal transporter from rice. J. Exp. Bot. 2002, 53, 1677-1682. [CrossRef]

38. Vert, G.; Grotz, N.; Dédaldéchamp, F.; Gaymard, F.; Guerinot, M.L.; Briat, J.F.; Curie, C. IRT1, an Arabidopsis transporter essential for iron uptake from the soil and for plant growth. Plant Cell 2002, 14, 1223-1233. [CrossRef]

39. Pedas, P.; Ytting, C.K.; Fuglsang, A.T.; Jahn, T.P.; Schjoerring, J.K.; Husted, S. Manganese efficiency in barley: Identification and characterization of the metal ion transporter HvIRT1. Plant Physiol. 2008, 148, 455-466. [CrossRef] [PubMed]

40. Kolaj-Robin, O.; Russell, D.; Hayes, K.A.; Pembroke, J.T.; Soulimane, T. Cation diffusion facilitator family: Structure and function FEBS Lett. 2015, 589, 1283-1295. [CrossRef]

41. Curie, C.; Cassin, G.; Couch, D.; Divol, F.; Higuchi, K.; Le Jean, M.; Misson, J.; Shikora, A.; Czernic, P.; Mari, S. Metal movement within the plant: Contribution of nicotianamine and yellow stripe 1-like transporters. Ann. Bot. 2009, 103, 1-11. [CrossRef] [PubMed]

42. Sinclair, S.A.; Krämer, U. The zinc homeostasis network of land plants. BBA Mol. Cell. Res. 2012, 1823, 1553-1567. [CrossRef]

43. Deinlein, U.; Weber, M.; Schmidt, H.; Rensch, S.; Trampczynska, A.; Hansen, T.H.; Husted, S.; Schjoerring, J.K.; Talke, I.N.; Krämer, U.; et al. Elevated nicotianamine levels in Arabidopsis halleri roots play a key role in zinc hyperaccumulation. Plant Cell 2012, 24, 708-723. [CrossRef] [PubMed] 
44. Foroughi, S.; Baker, A.J.M.; Roessner, U.; Johnson, A.A.T.; Bacic, A.; Callahan, D.L. Hyperaccumulation of zinc by Noccaea caerulescens results in a cascade of stress responses and changes in the elemental profile. Metallomics 2014, 6, 1671-1682. [CrossRef] [PubMed]

45. Foyer, C.H.; Lam, H.-M.; Nguyen, H.T.; Siddique, K.H.M.; Varshney, R.K.; Colmer, T.D.; Cowling, W.; Bramley, H.; Mori, T.A.; Hodgson, J.M.; et al. Neglecting legumes has compromised human health and sustainable food production. Nat. Plants 2016, 2, 16112. [CrossRef]

46. Aarts, M.G. Nicotianamine secretion for zinc excess tolerance. Plant Physiol. 2014, 166, 751-752. [CrossRef] [PubMed]

47. Clemens, S.; Deinlein, U.; Ahmadi, H.; Höreth, S.; Uraguchi, S. Nicotianamine is a major player in plant Zn homeostasis. Biometals 2013, 26, 623-632. [CrossRef] [PubMed]

48. Haydon, M.J.; Kawachi, M.; Wirtz, M.; Hillmer, S.; Hell, R.; Krämer, U. Vacuolar nicotianamine has critical and distinct roles under iron deficiency and for zinc sequestration in Arabidopsis. Plant Cell 2012, 24, 724. [CrossRef] [PubMed]

49. Desbrosses-Fonrouge, A.G.; Voigt, K.; Schröder, A.; Arrivault, S.; Thomine, S.; Krämer, U. Arabidopsis thaliana MTP1 is a Zn transporter in the vacuolar membrane which mediates $\mathrm{Zn}$ detoxification and drives leaf $\mathrm{Zn}$ accumulation. FEBS Lett. 2005, 579, 4165-4174. [CrossRef] [PubMed]

50. Hussain, D.; Haydon, M.J.; Wang, Y.; Wong, E.; Sherson, S.M.; Young, J.; Camakaris, J.; Harper, J.F.; Cobbett, C.S. P-type ATPase heavy metal transporters with roles in essential zinc homeostasis in Arabidopsis. Plant Cell 2004, 16, 1327-1339. [CrossRef]

51. Palmer, C.M.; Guerinot, M.L. Facing the challenges of Cu, Fe and Zn homeostasis in plants. Nat. Chem. Biol. 2009, 5, 333-340. [CrossRef] [PubMed]

52. Burleigh, S.H.; Kristensen, B.K.; Bechmann, I.E. A plasma membrane zinc transporter from Medicago truncatula is up-regulated in roots by Zn fertilization, yet down-regulated by arbuscular mycorrhizal colonization. Plant Molec. Biol. 2003, 52, 1077-1088. [CrossRef] [PubMed]

53. Sasaki, A.; Yamaji, N.; Mitani-Ueno, N.; Kashino, M.; Ma, J.F. A node-localized transporter OsZIP3 is responsible for the preferential distribution of $\mathrm{Zn}$ to developing tissues in rice. Plant J. 2015, 84, 374-384. [CrossRef]

54. Fageria, N.K.; Filho, M.B.; Moreira, A.; Guimarães, C.M. Foliar fertilization of crop plants. J. Plant Nutr. 2009, $32,1044-1064$. [CrossRef]

55. White, P.J. Long-distance transport in the xylem and phloem. In Marschner's Mineral Nutrition of Higher Plants; Academic Press: London, UK, 2012; pp. 49-70.

56. Cakmak, I.; Torun, A.; Millet, E.; Feldman, M.; Fahima, T.; Korol, A.; Nevo, E.; Braun, H.J.; Özkan, H. Triticum dicoccoides: An important genetic resource for increasing zinc and iron concentration in modern cultivated wheat. J. Soil Sci. Plant Nut. 2004, 50, 1047-1054. [CrossRef]

57. Cakmak, I. Enrichment of cereal grains with zinc: Agronomic or genetic biofortification? Plant Soil 2008, 302, 1-17. [CrossRef]

58. Cakmak, I.; Pfeiffer, W.H.; McClafferty, B. Biofortification of durum wheat with zinc and iron. Cereal Chem. 2010, 87, 10-20. [CrossRef]

59. White, P.J.; Thompson, J.A.; Wright, G.; Rasmussen, S.K. Biofortifying Scottish potatoes with zinc. Plant Soil 2017, 411, 151-165. [CrossRef]

60. Erenoglu, E.B.; Kutman, U.B.; Ceylan, Y.; Yildiz, B.; Cakmak, I. Improved nitrogen nutrition enhances root uptake, root-to-shoot translocation and remobilization of zinc ( $\left.{ }^{65} \mathrm{Zn}\right)$ in wheat. New Phytol. 2011, 189, 438-448. [CrossRef] [PubMed]

61. O’Rourke, J.A.; Fu, F.; Bucciarelli, B.; Yang, S.S.; Samac, D.A.; Lamb, J.F.; Li, J.; Dai, X.; Zhao, P.X.; Vance, C.P. The Medicago sativa gene index 1.2: A web-accessible gene expression atlas for investigating expression differences between Medicago sativa subspecies. BMC Genom. 2015, 16, 502. [CrossRef]

62. Hanikenne, M.; Krämer, U.; Demoulin, V.; Baurain, D. A comparative inventory of metal transporters in the green alga Chlamydomonas reinhardtii and the red alga Cyanidioschizon merolae. Plant Physiol. 2005, 137, 428-446. [CrossRef]

63. Wintz, H.; Fox, T.; Wu, Y.Y.; Feng, V.; Chen, W.; Chang, H.S.; Zhu, T.; Vulpe, C. Expression profiles of Arabidopsis thaliana in mineral deficiencies reveal novel transporters involved in metal homeostasis. J. Biol. Chem. 2003, 278, 47644-47653. [CrossRef]

64. Sinclair, S.A.; Senger, T.; Talke, I.N.; Cobbett, C.S.; Haydon, M.J.; Kraemer, U. Systemic upregulation of MTP2-and HMA2mediated $\mathrm{Zn}$ partitioning to the shoot supplements local Zn deficiency responses. Plant Cell 2018, 30, 2463-2479. [CrossRef] [PubMed]

65. Baker, A.J.; Whiting, S.N. In search of the Holy Grail—A further step in understanding metal hyperaccumulation? New Phytol. 2002, 155. [CrossRef]

66. Hanikenne, M.; Talke, I.N.; Haydon, M.J.; Lanz, C.; Nolte, A.; Motte, P.; Kroymann, J.; Weigel, D.; Krämer, U. Evolution of metal hyperaccumulation required cis-regulatory changes and triplication of HMA4. Nature 2008, 453, 391-395. [CrossRef] [PubMed]

67. Ó Lochlainn, S.; Bowen, H.C.; Fray, R.G.; Hammond, J.P.; King, G.J.; White, P.J.; Broadley, M.R. Tandem quadruplication of HMA4 in the zinc (Zn) and cadmium (Cd) hyperaccumulator Noccaea caerulescens. PLoS ONE 2011, 6, e17814. [CrossRef]

68. Andrés-Colás, N.; Sancenón, V.; Rodríguez-Navarro, S.; Mayo, S.; Thiele, D.J.; Ecker, J.R.; Puig, S.; Peñarrubia, L. The Arabidopsis heavy metal P-type ATPase HMA5 interacts with metallochaperones and functions in copper detoxification of roots. Plant J. 2006, 45, 225-236. [CrossRef] [PubMed]

69. Sankaran, R.P.; Huguet, T.; Grusak, M.A. Identification of QTL affecting seed mineral concentrations and content in the model legume Medicago truncatula. Theor. Appl. Genet. 2009, 119, 241-253. [CrossRef] [PubMed] 
70. Hermand, V.; Julio, E.; de Borne, F.D.; Punshon, T.; Ricachenevsky, F.K.; Bellec, A.; Gosti, F.; Berthomieu, P. Inactivation of two newly identified tobacco heavy metal ATPases leads to reduced $\mathrm{Zn}$ and $\mathrm{Cd}$ accumulation in shoots and reduced pollen germination. Metallomics 2014, 6, 1427-1440. [CrossRef] [PubMed]

71. Deshpande, P.; Dapkekar, A.; Oak, M.D.; Paknikar, K.M.; Rajwade, J.M. Zinc complexed chitosan/TPP nanoparticles: A promising micronutrient nanocarrier suited for foliar application. Carbohyd. Polym. 2017, 165, 394-401. [CrossRef] [PubMed]

72. Talke, I.N.; Hanikenne, M.; Krämer, U. Zinc-dependent global transcriptional control, transcriptional deregulation, and higher gene copy number for genes in metal homeostasis of the hyperaccumulator Arabidopsis halleri. Plant Physiol. 2006, 142, 148-167. [CrossRef] [PubMed]

73. Becher, M.; Talke, I.N.; Krall, L.; Krämer, U. Cross-species microarray transcript profiling reveals high constitutive expression of metal homeostasis genes in shoots of the zinc hyperaccumulator Arabidopsis halleri. Plant J. 2004, 37, 251-268. [CrossRef]

74. Weber, M.; Harada, E.; Vess, C.; Roepenack-Lahaye, E.V.; Clemens, S. Comparative microarray analysis of Arabidopsis thaliana and Arabidopsis halleri roots identifies nicotianamine synthase, a ZIP transporter and other genes as potential metal hyperaccumulation factors. Plant J. 2004, 37, 269-281. [CrossRef] [PubMed]

75. Gustin, J.L.; Loureiro, M.E.; Kim, D.; Na, G.; Tikhonova, M.; Salt, D.E. MTP1-dependent Zn sequestration into shoot vacuoles suggests dual roles in Zn tolerance and accumulation in Zn-hyperaccumulating plants. Plant J. 2009, 57, 1116-1127. [CrossRef]

76. Jean, M.L.; Schikora, A.; Mari, S.; Briat, J.F.; Curie, C. A loss-of-function mutation in AtYSL1 reveals its role in iron and nicotianamine seed loading. Plant J. 2005, 44, 769-782. [CrossRef] [PubMed]

77. Zhang, H.; Zhao, S.; Li, D.; Xu, X.; Li, C. Genome-wide analysis of the ZRT, IRT-Like protein (ZIP) family and their responses to metal stress in Populus trichocarpa. Plant Mol. Biol. Rep. 2017, 35, 534-549. [CrossRef]

78. Ivanov, R.; Bauer, P. Sequence and coexpression analysis of iron-regulated ZIP transporter genes reveals crossing points between iron acquisition strategies in green algae and land plants. Plant Soil 2017, 418,61-73. [CrossRef]

79. Sharma, S.S.; Dietz, K.J.; Mimura, T. Vacuolar compartmentalization as indispensable component of heavy metal detoxification in plants. Plant Cell Environ. 2016, 39, 1112-1126. [CrossRef]

80. Pita-Barbosa, A.; Ricachenevsky, F.K.; Wilson, M.; Dottorini, T.; Salt, D.E. Transcriptional plasticity buffers genetic variation in zinc homeostasis. Sci. Rep. 2019, 9, 19482. [CrossRef] [PubMed]

81. Li, S.; Zhou, X.; Huang, Y.; Zhu, L.; Zhang, S.; Zhao, Y.; Chen, R. Identification and characterization of the zinc-regulated transporters, iron-regulated transporter-like protein (ZIP) gene family in maize. BMC Plant Biol. 2013, 13, 114. [CrossRef] [PubMed]

82. Yilmaz, O.; Kazar, G.A.; Cakmak, I.; Ozturk, L. Differences in grain zinc are not correlated with root uptake and grain translocation of zinc in wild emmer and durum wheat genotypes. Plant Soil 2017, 411, 69-79. [CrossRef]

83. Nölte, J. ICP Emission Spectrometry: A Practical Guide; Wiley-VCH: Weinheim, Germany, 2003; Volume 1.

84. Haydon, M.J.; Cobbett, C.S. A novel major facilitator superfamily protein at the tonoplast influences zinc tolerance and accumulation in Arabidopsis. Plant Physiol. 2007, 143, 1705-1719. [CrossRef] [PubMed]

85. Nicot, N.; Hausman, J.F.; Hoffmann, L.; Evers, D. Housekeeping gene selection for real-time RT-PCR normalization in potato during biotic and abiotic stress. J. Exp. Bot. 2005, 56, 2907-2914. [CrossRef] [PubMed]

86. Chen, M.; Shen, X.; Li, D.; Ma, L.; Dong, J.; Wang, T. Identification and characterization of MtMTP1, a Zn transporter of CDF family, in the Medicago truncatula. Plant Physiol. Biochem. 2009, 47, 1089-1094. [CrossRef] [PubMed]

87. Desjardins, P.; Conklin, D. NanoDrop microvolume quantitation of nucleic acids. JOVE 2010, 5, e2565. [CrossRef] [PubMed]

88. Livak, K.J.; Schmittgen, T.D. Analysis of relative gene expression data using real-time quantitative PCR and the $2^{-\Delta \Delta C T}$ method. Methods 2001, 25, 402-408. [CrossRef] [PubMed]

89. Kumar, S.; Stecher, G.; Li, M.; Knyaz, C.; Tamura, K. MEGA X: Molecular evolutionary genetics analysis across computing platforms. Mol. Biol. Evol. 2018, 35, 1547-1549. [CrossRef] [PubMed]

90. Saitou, N.; Nei, M. The neighbor-joining method: A new method for reconstructing phylogenetic trees. Mol. Biol. Evol. 1987, 4, 406-425. [CrossRef] [PubMed]

91. Nei, M.; Kumar, S. Molecular Evolution and Phylogenetics; Oxford University Press: Oxford, UK, 2000.

92. Anderson, M.J. A new method for non-parametric multivariate analysis of variance. Austral. Ecol. 2001, 26, 32-46. [CrossRef]

93. Anderson, M.; Braak, C.T. Permutation tests for multi-factorial analysis of variance. J. Stat. Comput. Sim. 2003, 73, 85-113. [CrossRef]

94. Anderson, M.J.; Ellingsen, K.E.; McArdle, B.H. Multivariate dispersion as a measure of beta diversity. Ecol. Lett. 2006, 9, 683-693. [CrossRef] [PubMed]

95. Clarke, K.R.; Gorley, R.N. Getting Started with PRIMER v7; Plymouth Marine Laboratory: Plymouth, UK, 2015.

96. Wickham, H. ggplot2. WIREs Comput. Stat. 2011, 3, 180-185. [CrossRef] 